
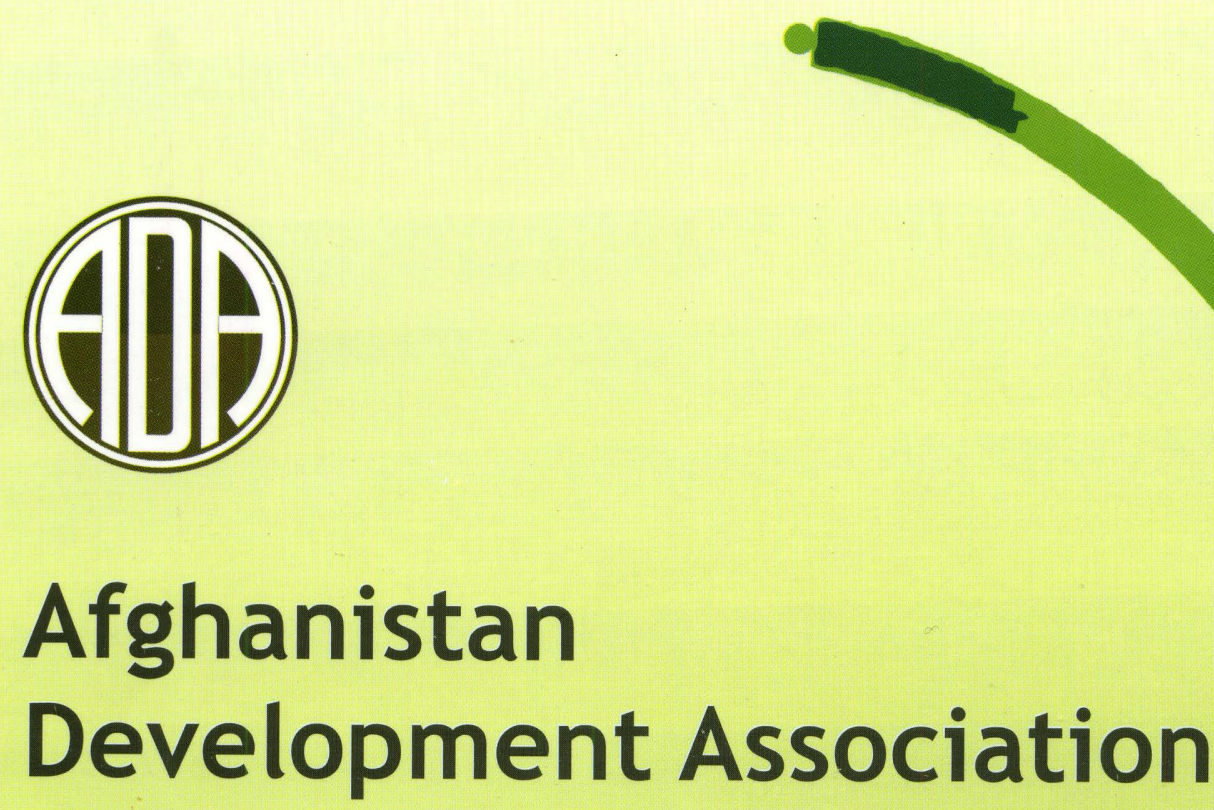

Afghanistan

Development Association

Empowering people, eradication of poverty, and promoting social justice and peace

\title{
Annual Report 2010
}




\section{Afghanistan \\ Development Association}

Empowering people, eradication of poverty, and promoting social justice and peace

\section{Annual Report 2010}

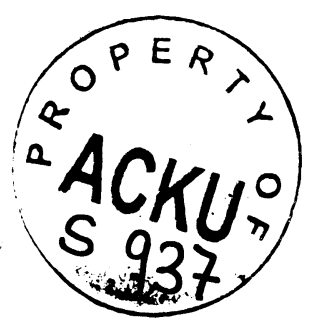




\section{TABLE OF CONTENT}

Capacity Building

Training for Agriculture Depots 03

Rights Education \& Community Organization

Community Based Disaster Risk Reduction

06

Emergency Preparedness \& Response

Vocational Training

Business \& Marketing Training

Enhancement in Enrolment of Girls and uality of Education

Study of the Impact of Climate Change and Food Insecurity on Poverty

CBSG Programme: Badakhshan, Takhar, Kunduz, Pansher and Baghlan 10-19

EXPENDITURE FOR THE YEAR 2010 - Capacity Building Department

Education

Women Empowerment - Basic Literacy

Women Empowerment - Economics

Climate Change Mitigation

Building Education Support System for Teachers (BESST) 31

Education Quality Improvement Program (EQUIP-II)

EXPENDITURE FOR THE YEAR 2010 - Education Department

AG\&L in Uruzgan, Kandahar, Zabul, Ghazni, Nangarhar, Baghlan, Daykundi

AG\&L Activities Summary during 2010

EXPENDITURE FOR THE YEAR 2010 - Agriculture \& Livestock Department 


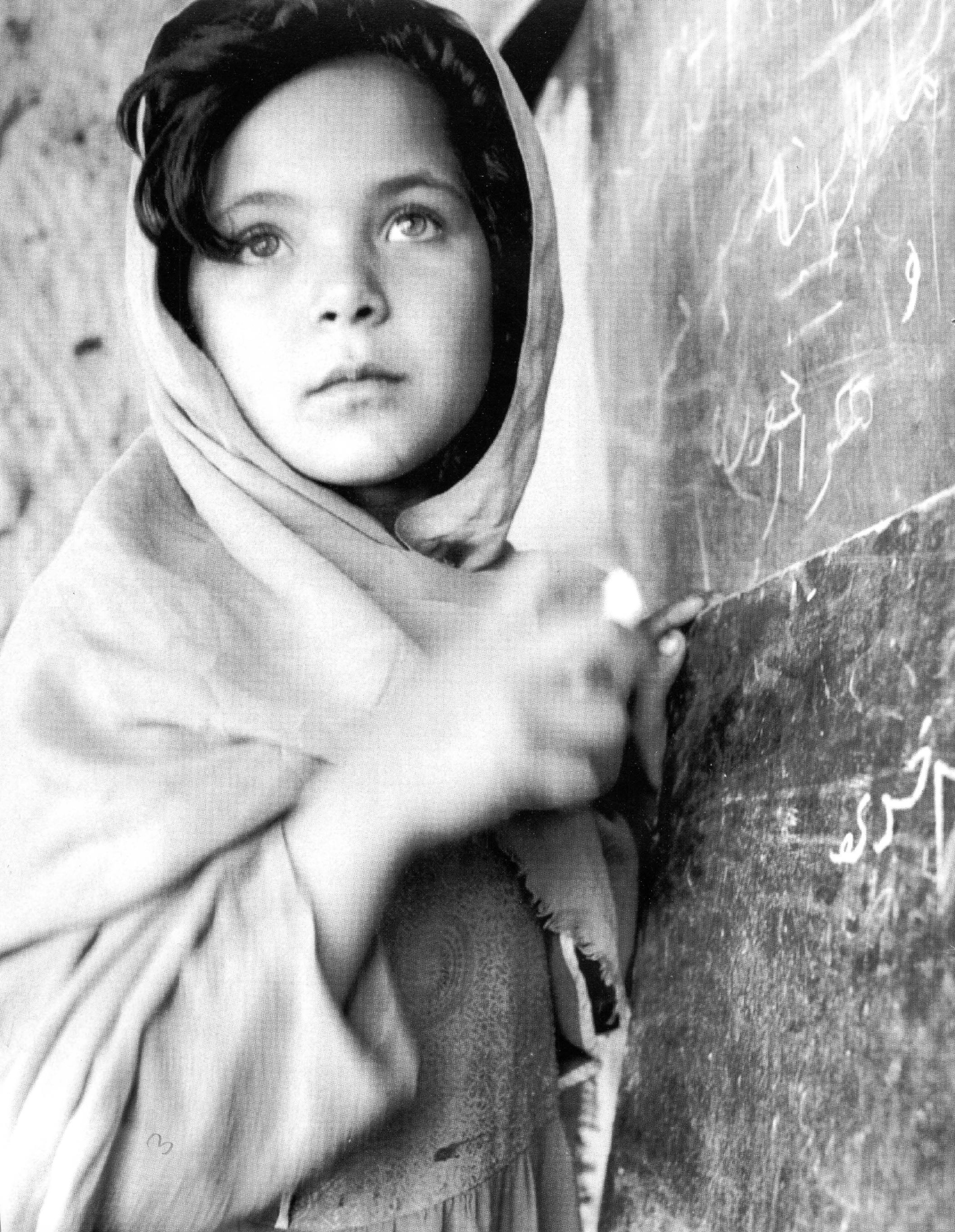




\section{BACKGROUND}

Afghan Development Association (ADA) is a Non Government Organization (NGO) registered with Ministry of Economy (MoEc) and has more than two decades experiences; in implementing emergency assistance, rehabilitation and development of projects through integrated rural development approaches in South, West, North, North East, East, and Center Region of Afghanistan. ADA vision remains eradication of poverty from Afghanistan and committed to fight the complex issue of poverty by working for restoration of civil rights, including enabling the poor to gain access to basic services including health, education and social justice.

ADA is committed to fight all kinds of discrimination and to enable families to gain access to their rights and actively be involved in the development of their destinies.

During 2010, ADA implemented integrated rural development programme with the financial and technical support from international and local communities; ADA implemented multi-sector rehabilitation and development projects, which were designed to foster self-reliance and selfsufficiency; in addition to empowering Afghans to meet their future needs, ADA has been creating the socio-economic conditions to promote peace and stability.

During 2010, ADA management members actively took part in events, conferences, forums and gatherings at both national and international levels in order to pave the way for all to focus on costeffective and quality programs, and to minimize the risks and mistakes through coordinated and listen learned approaches.

ADA's past years achievements brought about positive changes in the social, economical and political aspects of targeted people through achievements focused on their skills, knowledge, and their understanding of development and subjects on cross-cutting issues. The community development work was the integral part of ADA each intervention. 


\section{ACKNOWLEDGMENTS}

The preparation of this ADA 2010 report was made possible due to contribution of many individuals, teams and organizations that really become part of the great achievements and now ADA is proud to compile these achievements in this report.

ADA management would like to thank those who achieved the technical progress related to this report, and the managers who supported and directed the work. The foremost gratitude goes to ADA's field staff members and teams that despite of being in an insecure and sometimes difficult environment they continued to work in the targeted communities with utmost dedication and commitment.

Special acknowledgment and thanks go to the participating communities and their organizations who gave unconditional support and cooperation to the projects and programmes.

$\mathrm{ADA}$ is also grateful to its donors both national (Ministry of Education (MoE) and Ministry of Agriculture, Irrigation and Livestock (MAIL) and international (European Commission (EC), Christian Aid (CA), Church World Services (CWS), International Organization for Migration Mission in Afghanistan (IOM), ACDI/VOCA, Action Centre La Faim (ACF), CARE International, Norwegian Church Aid (NCA), World Bank Group -WPG (IFC-WBG), who believed in ADA's commitment to serve the Afghan people and provided financial and moral support for the successful achievements of the whole programme.

Acknowledgment goes to ADA 2010 Report preparation team (Managing Director, Deputy Managing Director, Line Directors, Managers and Officers) that give their valuable time in preparation of this report and specially thanks and acknowledgment go to Ahmad Kakar who give his much time in designing the report in utmost reader friendly and visual manner.

Last but not least, we are grateful to all good friends of ADA who contributed in reviewing the first draft of this report and made valuable comments and revisions that made a smooth reading of this document possible. 


\section{ABBREVIATIONS}

ADA

AFGHAN DEVELOPMENT ASSOCIATION

ARD

ASSOCIATES IN RURAL DEVELOPMENT

\section{BESST}

BASIC EDUCATION SUPPORT SYSTEM FOR

TEACHERS

\section{BVW}

BASIC VETERINARY WORKER

CA

CHRISTIAN AID

CBO

COMMUNITY BASED ORGANIZATION

CDCS

COMMUNITY DEVELOPMENT COUNCILS

CDPs

COMMUNITY DEVELOPMENT PLANS

CIDA

CANADIAN INTERNATIONAL DEVELOPMENT

AGENCY

CWS

CHURCH WORLD SERVICE

DAI

DEVELOPMENT ALTERNATIVES INC

DAP

DI-AMMONIUM PHOSPHATE

DRR

DISASTER RISK REDUCTION

DT3

DISTRICT TEACHER TRAINING TEAM
EC

EUROPEAN COMMISSION

FAO

FOOD AND AGRICULTURAL ORGANIZATION

GOA / GIROA

GOVERNMENT OF AFGHANISTAN/

GOVERNMENT ISLAMIC REPUBLIC OF

AFGHANISTAN

INSET

IN SERVICE TRAINING

IRD

INTEGRATED RURAL DEVELOPMENT

M\&E

MONITORING AND EVALUATION

MAIL

MINISTRY OF AGRICULTURE, IRRIGATION AND LIVESTOCK

\section{MOE}

MINISTRY OF EDUCATION

MOLSMD

MINISTRY OF LABOR AND SOCIAL AFFAIRS, MARTYRS AND DISABLED

MOU

MEMORANDUM OF UNDERSTANDING

\section{MRRD}

MINISTRY OF RURAL REHABILITATION AND DEVELOPMENT

\section{MT}

METRIC TON

NCA

NORWEGIAN CHURCH AID 


\section{... Continue Abbreviations}

NGO

NON-GOVERNMENTAL ORGANIZATION

NOVIB

NETHERLANDS ORGANIZATION FOR

INTERNATIONAL DEVELOPMENT

A\&LD

AGRICULTURE AND LIVESTOCK DEPARTMENT

PCO

PUBLIC CALL OFFICE

VFU

VETERINARY FIELD UNIT

VFW

VETERINARY FIELD WORKER

UN

UNITED NATION
WB

WORLD BANK

WPCO

WOMEN PUBLIC CALL OFFICE

FMI

FOR MORE INFORMATION

\section{CBD}

CAPACITY BUILDING DEPARTMENT

ED

EDUCATION DEPARTMENT

NFI

NON FOOD ITEMS

FMI

FOOD ITEMS 


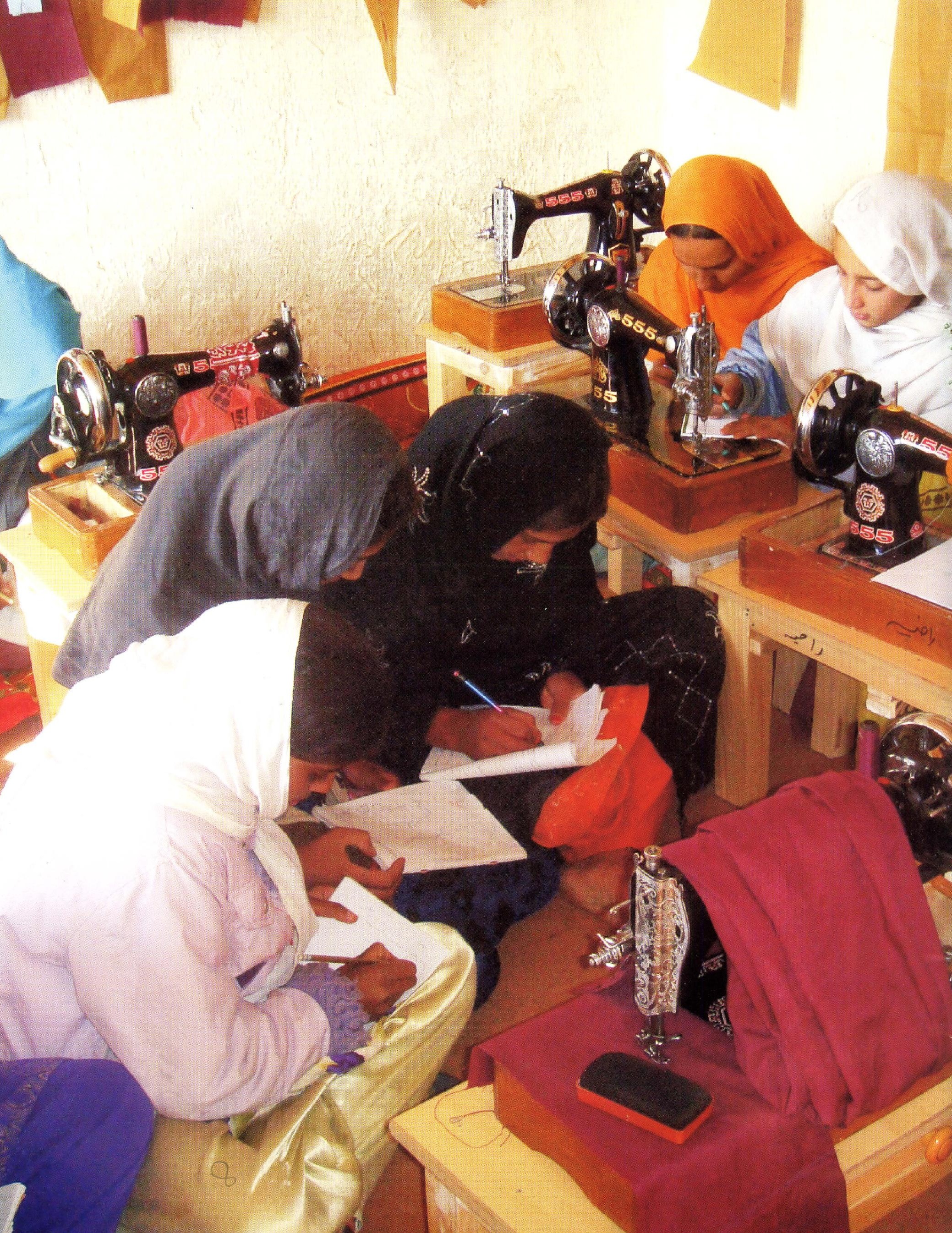




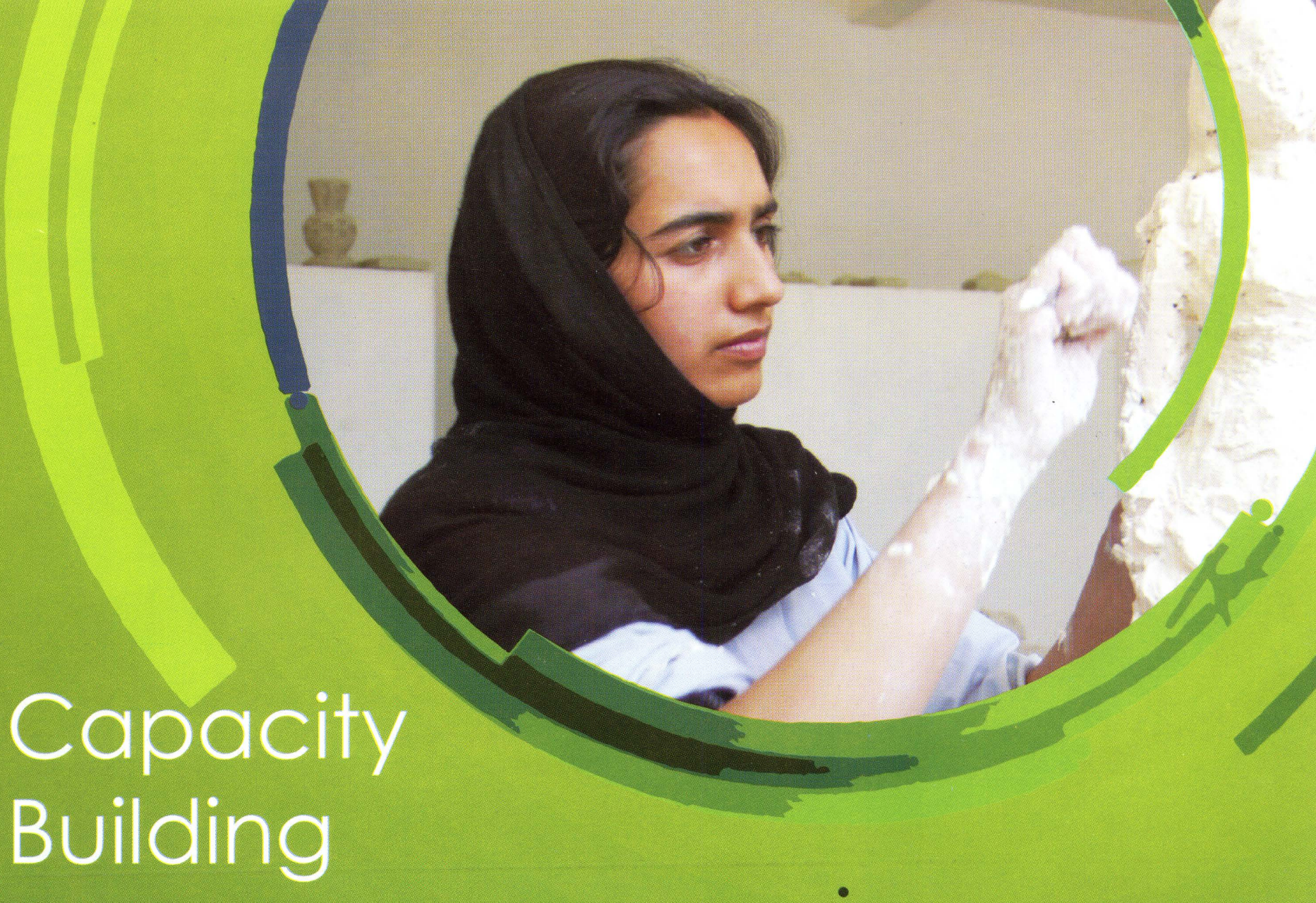

\section{Efforts of 2010}

Capacity Building is the integral part of ADA mission. During the year 2010 the programme made substantial contribution to the capacity development of local government officials and community members. The diverse, but interrelated thematic focussed on organizational development, gender and peace development approaches, rights education and skill training, improvement of agriculture depots, raising awareness of local government and communities on disaster risk reduction and advocacy relevant practices.

The programme focussed on training in many areas such as training in agricultural departments in four provinces, rights education and community organization, community based disaster risk reduction, vocational training to vulnerable women and marginalised groups, girls' education, emergency preparedness and response, impact of climate change on agriculture and community based stabilization grant projects.
The scope of ADA capacity building programme would be broadened through a sustainable focus on building Afghan peace locally programme. This programme will continue its efforts for knowledge development via research and networking. During the year 2010, the Capacity Building Department implemented different projects, which mostly targeted women empowerment, children education, community stability, disaster risk reduction research and advocacy.

During the year of 2010 , more than 70,000 people including 5,000 women and 25,000 children have benefited directly and more than 500,000 people including $45 \%$ female have benefited indirectly from the projects. Thus, ADA Capacity Building Department successfully implemented the following projects in various locations. 


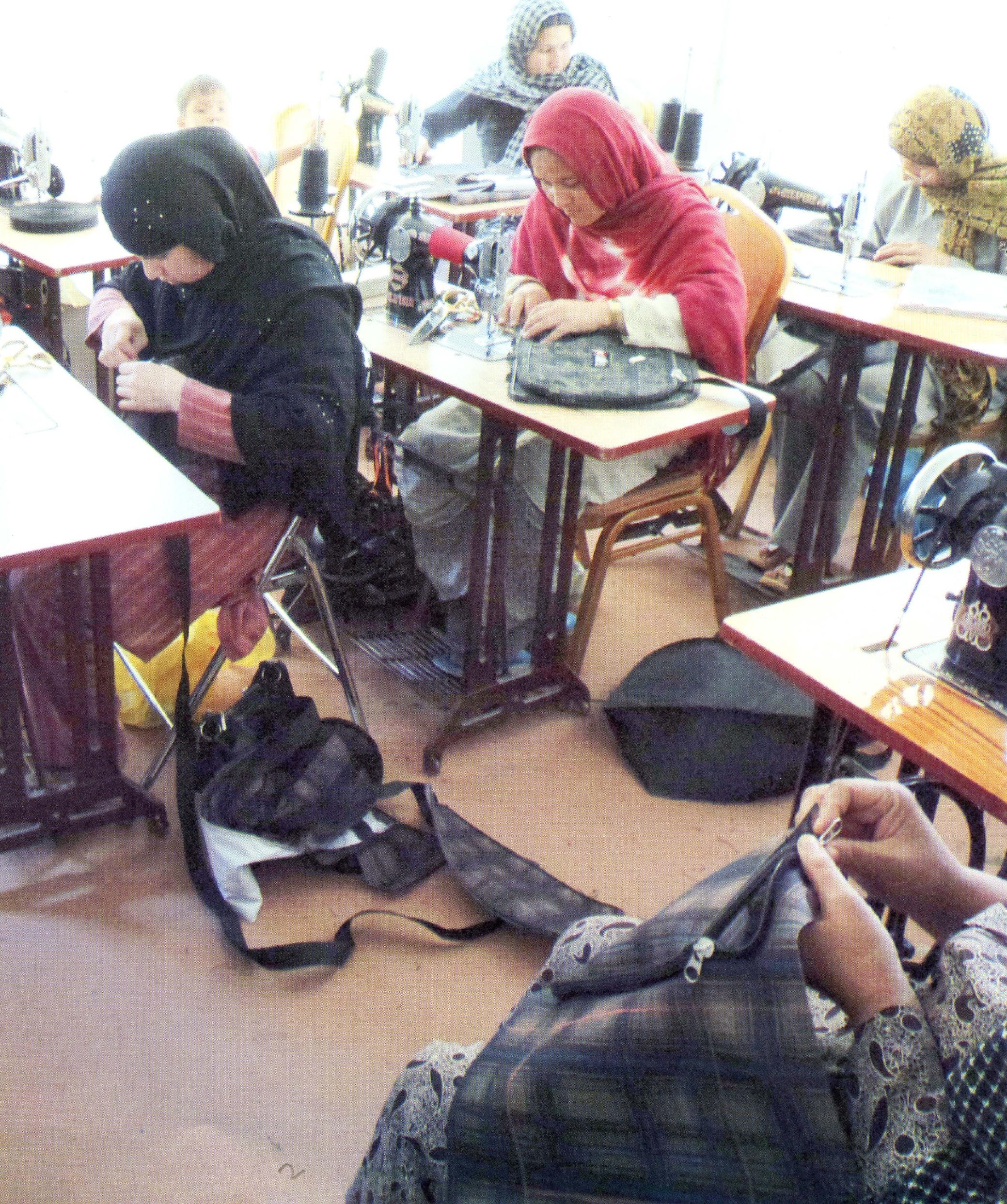




\section{Training for Agriculture Depots:}

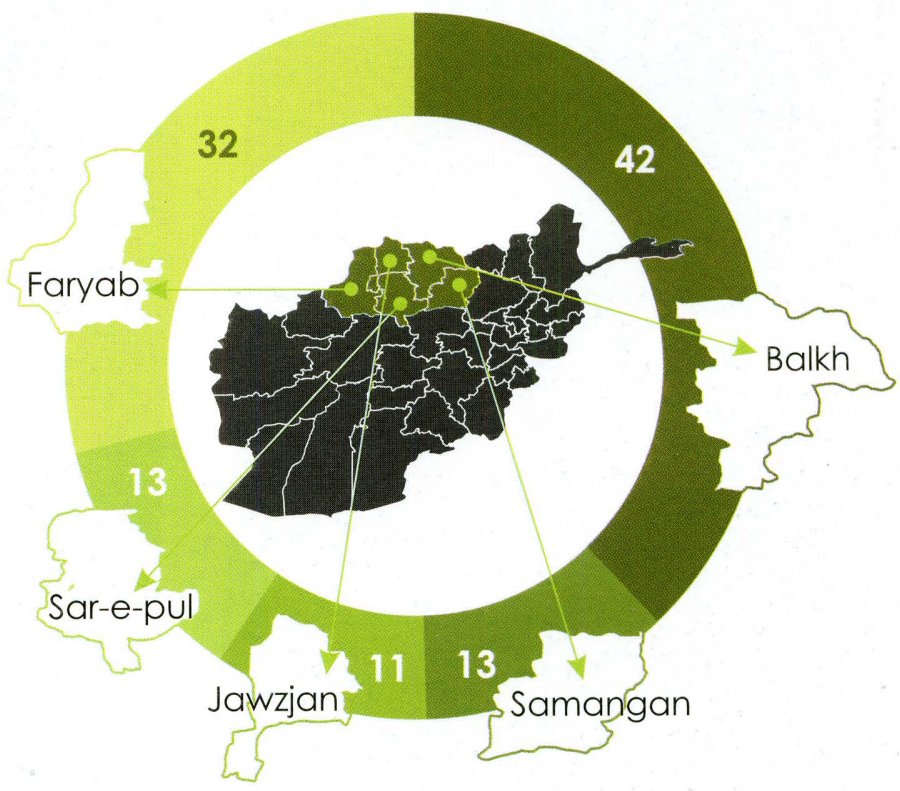

The aim of this project was to improve capacity of 7 agriculture depots in the North part of Afghanistan in bookkeeping, income management systems, and inventory control. ADA has successfully delivered the training to achieve the aim of this project and has trained in seven workshops 111 members in five different provinces; such as, Samangan, Balkh, Jawzjan, Sar-e-Pul and Faryab.

\section{Achievements}

Through implementation of this project, ADA has established 40 circles (CBOs/ alliances) of marginalized groups ( 25 from female and 15 from male*) in three districts of Faryab province. Also ADA has trained 630 the most vulnerable women as, 156 in carpet weaving, 320 in Gilam weaving, 70 in embroidery and 90 in tailoring with the provision of complete tool kits for the target

Rights Education \& Community Organization:

The aim of this project was to enhance awareness in rights and provide vocational training to marginalized groups such as widows, disabled and land-less people. .

At the end, they would collectively engage with institutions of the state and other development actors to ensure the realization of rights to food security, livelihood and human security. trainees, as (78 carpet weaving looms/frames, 160 Gilam weaving looms, 70 embroidery machines and 90 tailoring machines) for these circles during the year 2010. 300 trainees have been selected, trained and so on the green-house tools have been provided to them, indeed the tools were needed for the kitchen gardening training and utilization practices.

Note: *It is worth mentioning that 15 circles (CBOs) were established during the 2009 in Balchiragh district of Faryab province. 


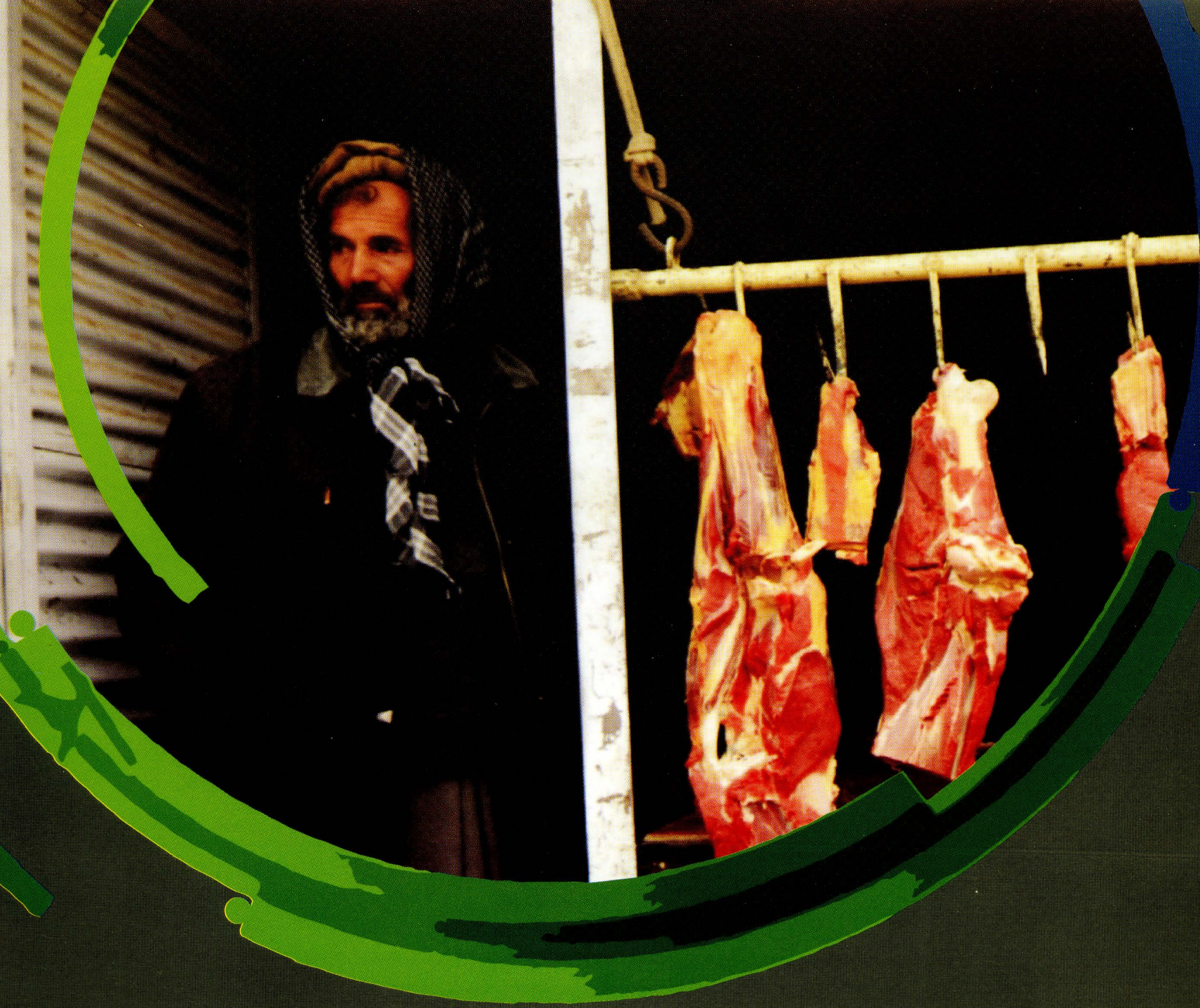

\section{Case Story | Dost Mohammad}

My name is Dost Mohammad; I work as a butcher. My income is not covering my monthly expenditure and each month I need to get loan to cover my expenditure. This load is breading my backbone thinking how to recover the overspent and I remain more under psychological pressure.

One day when I sold my last income source (Cow and Goats ) in Bazaar, Mr. Kfiaberdi saw me and told me that an organization by the name of ADA is working here that is conducting training for vulnerable people to know their rights and distributing thread for Galim weaving. You can go and ask their assistance. Mr. Kfiaberdi introduced me to Mr. Abdul Momin who is a representative of one Reflect Circle in Grizwan district. After meeting him, I participated in circle activities that was very interesting for me. I heard more new things for the first time like human rights and law. When I came back to my house I shared the story with my mother and sisters. They were also inspired through me and wanted to join female circle. Mrs. Khadija help us and include my mother and two sisters in female circles activities. After few months of ADA trainings, the circle members selected my sister for Tailoring training and my mother and my second sister for Galim viewing.

Now I am feeling better as I know more things about rights as human rights, law, and gender. We have learned new skills (Tailoring and Galim weaving) and also we can read, write, and understand simple sentences. We improve our economic status with these skills. My sister is working hard to sew cloths after this training. This remains a good income source to our family. I purchased two goats and now trying to increase the number of goats next year. Our circle sold the Galim we weaved in market and I earned some money from selling the Galim. Yes, ADA has changed my live. Thanks you ADA and whoever is supporting this program. 


\section{Beneficiaries as per District:}

\begin{tabular}{|c|c|c|c|c|c|c|c|c|c|c|}
\hline \multirow[t]{2}{*}{ No } & \multirow{2}{*}{$\frac{\text { Training }}{\text { District }}$} & \multicolumn{2}{|c|}{$\begin{array}{l}\text { Circle } \\
\text { Established }\end{array}$} & \multirow{2}{*}{$\begin{array}{l}\text { Human Right } \\
\text { Education } \\
\end{array}$} & \multirow[t]{2}{*}{ Literacy } & \multirow[t]{2}{*}{ Tailoring } & \multirow[t]{2}{*}{$\begin{array}{l}\text { Embroi- } \\
\text { dery }\end{array}$} & \multirow[t]{2}{*}{$\begin{array}{l}\text { Carpet } \\
\text { Weaving }\end{array}$} & \multirow[t]{2}{*}{$\begin{array}{l}\text { Gilam } \\
\text { Weaving }\end{array}$} & \multirow[t]{2}{*}{$\begin{array}{l}\text { Kitchen } \\
\text { Gardening }\end{array}$} \\
\hline & & Male & Female & & & & & & & \\
\hline 01 & Balchiragh & 8 & 7 & 460 & 460 & 44 & 24 & 156 & 0 & 0 \\
\hline 02 & Gurziwan & 10 & 5 & 400 & 400 & 46 & 46 & 0 & 320 & 0 \\
\hline \multirow[t]{2}{*}{03} & Pashton-kot & 7 & 3 & 500 & 500 & 0 & 0 & 0 & 0 & 0 \\
\hline & TOTAL & 25 & 15 & 1,360 & 1,360 & 90 & 70 & 156 & 320 & 300 \\
\hline
\end{tabular}

ADA has established linkage between the circles and market and between the circles and department of women affairs for sustainability of the programme.

- Almost 880 members of circles (men and women) participated in free discussions about rights and laws according to the project plan (for detail; please see the brief report of circles' activities).

- Free discussions about rights and social affairs; such as, corruption, good governance, narcotics and its harm for humans, gender, poverty analysis, women and children rights, conflict management, poverty indicators, alternative of poppy cultivation, resource of government incomes, provincial council and its responsibilities, parliament responsibilities, votes and election have been facilitated in each circle.

- Literacy education process facilitated in each circle by REFLECT methods as, writing on the ground and in air by fingers and parables, usage of board and old news papers. 


\section{Community Based Disaster Risk Reduction:}

The focus of this project was awareness rising on climate changes, coping mechanism with disaster, development of contingency planning at village and district levels and construction of small mitigation structures and water reservoirs. The goal of the project was to enhance the resilience of communities in 20 villages/communities in Nahreen district through training and small - scale structural disaster mitigation project.

\section{Achievements}

- ADA trained 173 individuals including 95 male and 78 female in community based disaster risk management, sphere, conflict management, gender, rescue and in first aid activites.

- ADA established disaster management unit at district level to manage all types of disasters and improve linkage of village disaster committee with district and provincial disaster committees.

- ADA developed 23 contingency plans at the village level and one contingency plan at the district level.

- 4 protection and two retaining walls have been constructed to protect houses, 200 hectors agriculture land, 6 orchards and canals during flash floods.

- 20 water reservoirs have been constructed for rain water to increase the water table of underground water.

- 1,435 kg of new variety of wheat seed, which needs less water and has more resistance against drought, has been distributed to 41 farmers.

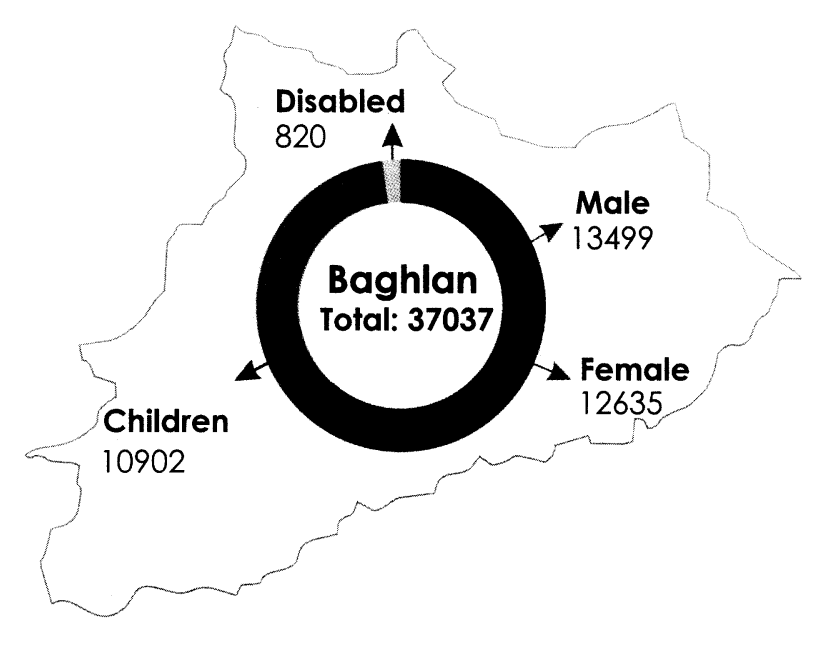

\section{Emergency Preparedness \& Response:}

During the year 2010, ADA implemented emergency preparedness and response project in Kandahar and Zabul provinces. Through this project hundreds of affected families have been assisted by NFI packages in Spin Boldak district and Kandahar city; it also helped Afghan National Disaster Management Authority (ANDMA) in rapid assessment of flash flood disaster in Zabul province. Through this project ADA has distributed 500 winterization NFI packages in Tirinkot district of Uruzgan province to IDPs who came from very remote districts of Uruzgan. FMI, the Non Food Items were provided by IOM to the targeted people. 



\section{Business \& \\ Marketing Training}

ADA has planned to train graduated skilled trainees on business and marketing techniques. During the year 2010 , totally 112 trainees including $79 \%$ of female have been trained who were graduated from different trades as embroidery, computer, mobile repairing, leather sewing, bag making, metal work and beautician. ADA has provided on job training facilities for all graduated trainees in different enterprises according to their skills in Kabul city. Also ADA has made three producer groups of interested trainees, 13 in leather sewing, 14 in bag making and 9 in beautician skills. Totally 36 trainees have been organized in these groups. It is well said that the literacy training was also included in these trainings

\section{Enhancement in Enrolment of Girls and Quality of Education:}

The enhancement in enrolment of girls and quality of education project aim is to contribute to increase/strengthen girls' participation and their retention in education and an overall improvement in quality of teaching and learning in primary schools of Qarghai district in Laghman province of Afghanistan. It will be achieved by increasing girls' enrolment and retention in 15 targeted schools, providing quality education, community awareness in importance of children/girls' education, and increased coordination among parents, teachers, and the line departments.

This project is the continuation of the girls' education project as its second phase, which was implemented in Qarghai district of Laghman province.

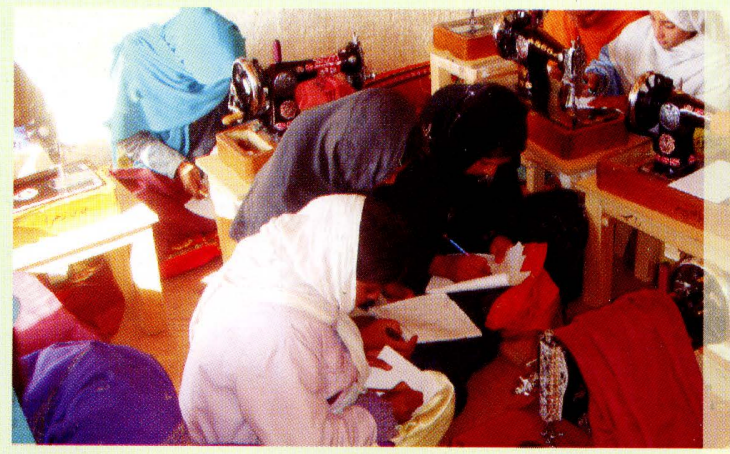

(ifi

Learning according needs of market will change your live.

\section{Achievements}

- 275 new girls/ students have been identified and enrolled in schools.

- 15 schools have been surveyed and 150 teachers interviewed and selected for teacher training practices.

- 4 new parents and teachers committees have been established in four new selected schools of Qarghai district in Laghman province.

- 58 CDC and PTC members have been trained in gender, children rights, and importance of girls' education in the target locations.

- One literacy and vocational training centre has been established for 30 house headed widows in Qarghai district of Laghman province.

- 1,800 educational tool kits with 1,800 school bags have been provided for 1,800 students in the target schools of Qarghai district. 


\section{Study of the Impact of Climate Change and Food Insecurity on Poverty:}

The aim of the study was to assess the impact of climate change on crop yield in four South Asian countries likeAfghanistan, Pakistan, Bangladesh and India. The study provided an insightful analysis of the ground realities by collecting primary data about the perception and recorded impact of climate change on crop yield at the gross root level most importantly among small and marginalized farmers. This Study was conducted in four South Asian countries - Afghanistan, Bangladesh, India and Pakistan.

ADA is the focal NGO for this study in Afghanistan, which implemented the project in three different provinces and three different climates zones including Kandahar, Nangarhar and Panjshir. We expected that the study would enhance our understanding of the impact that climate change could have on agriculture. Through this study we could raise awareness and suggest measures for coping with climate change induced problems to the national governments and their allies among the governments of the rich nations of the world. Also, since the same survey conducted in four aforementioned South Asian nations as a combined intervention of adaptation and mitigation practices would be possible giving rise to replication of success stories and the generation of synergies.

\section{Main Activities/Achievements:}

- ADA has conducted survey in 3 provinces of three different climate zones and interviewed 300 small and marginalized farmers.

- ADA has interviewed more than 25 professional and technical persons.

- ADA participated in two joint workshops and conferences about the climate changes in the South Asian country based in New Delhi, India.

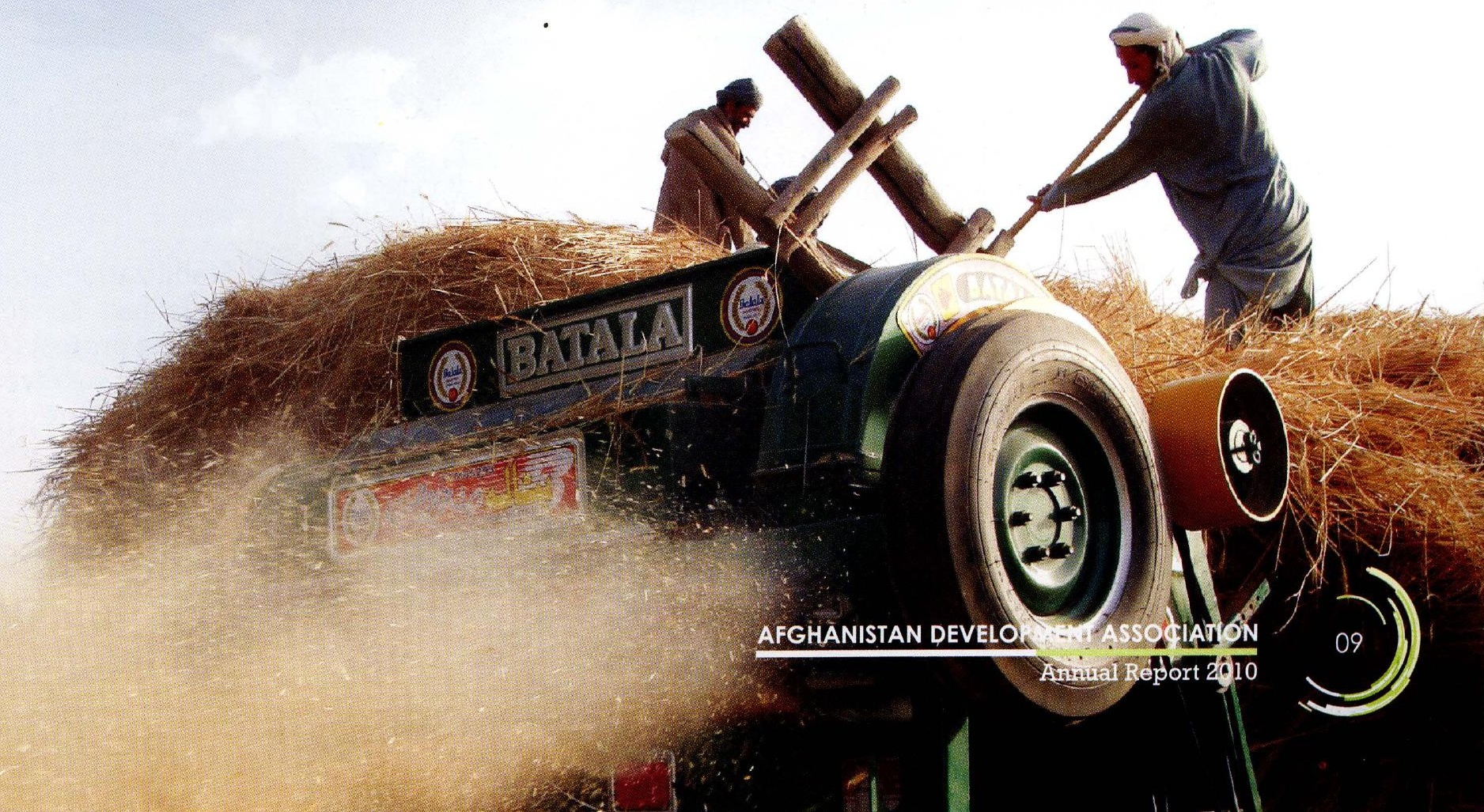




\section{Community Based Stabilization Grant Programme:}

Creative Associates International Inc. (CAII) is the prime contractor for the programme in Afghanistan. For the CBSG Programme Creative will be coordinating and overseeing the work of the Afghan sub-contractors who are functioning as programme implementing partners; the Afghan Development Association (ADA) together with its partner Creative applied community development practices and processes to enable unstable communities, to directly implement small-scale community-level projects. Programme grant activities will be provided for these small-scale community-level projects, which are designed to:

- Support stability initiatives in an effort to improve peace in unstable communities.

- Support the MRRD National Solidarity Programme (NSP), the Afghanistan Rural Enterprise Development Programme (ARED) and National Area Based Development Programme (NABDP) activities by linking GIRoA to communities, thereby building trust between the government and its rural citizens.

- Ensure a rapid response to express community development needs through advancing community mobilization strategies and efforts.

A major goal will be; to incorporate into the programme as many different district level groups and associative structures as possible. Activities will include, but not be exclusive to, small infrastructures repairs and development, material and equipment procurements and emergency response support

A fundamental objective of CBSG is to maximize the amount of Host Country National (HCN) staff involved directly and indirectly in implementation of programme as a part of the "Afghan First" initiative. Creative will achieve this objective by not only minimizing the amount of expatriate staff employed on the programme, but by sub-contracting ADA. The implementing partners will each be responsible for facilitating district level grants development in targeted districts within one of three regional areas of geographic focus. All activities shall be performed in accordance with the terms of the USAID Cooperative Agreement.

\section{CBSG Objective}

The objective of the CBSG Programme is to enable unstable communities, currently the focus of counter insurgency (COIN) activities, to directly implement small-scale communitylevel projects and build their confidence in and support for the GIRoA. The CBSG Programme will also bolster and further support those communities that have resisted insurgency and be utilized to further extend the writ of the GIRoA and expand and deepen its links with communities within its targeted districts.

The following provinces are under the operation of CBSG project.

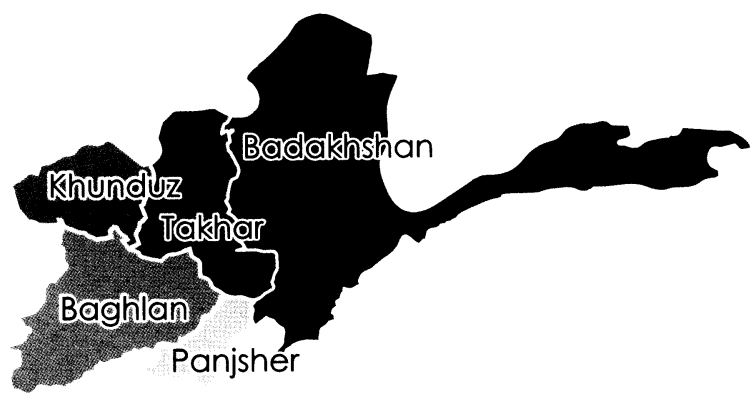

Under CommunityBased Stabilization Grant Programme in Badakhshan, Takhar, Kunduz, Baghlan and Panjshir the following projects by province-wise have been selected, surveyed, completed and handed over to community till end of December 2010. 


\section{BAGHLAN}

\section{Services}

\section{Beneficiaries}

Total: 5 Schools, 60 Families

7000 Students, 213 Teachers

10400 Students, 297 Teachers,

\section{Facilities \& Distribution;}

13200 Benches \& Desks for students

285 Desk/Chairs for teacher

210 Blackboard

310 Bookshelf

244 m2 Carpet

18 Tents

1 Construction of School

1 Construction of surrounding walls

25200 Benches \& Desks for students

325 Desk/Chairs for teacher

173 Blackboard

113 Bookshelf

346 m2 Carpet

1 Construction of School

\section{Activities:}

Project Mobilization, Survey, Proposal Development, Supervision \& Monitoring

Community Center Rehabilitation, Purchasing Equipments of Blood Bank

2 Bridge Rehabilitation (Ring Walls) and Surrounding wall Construction

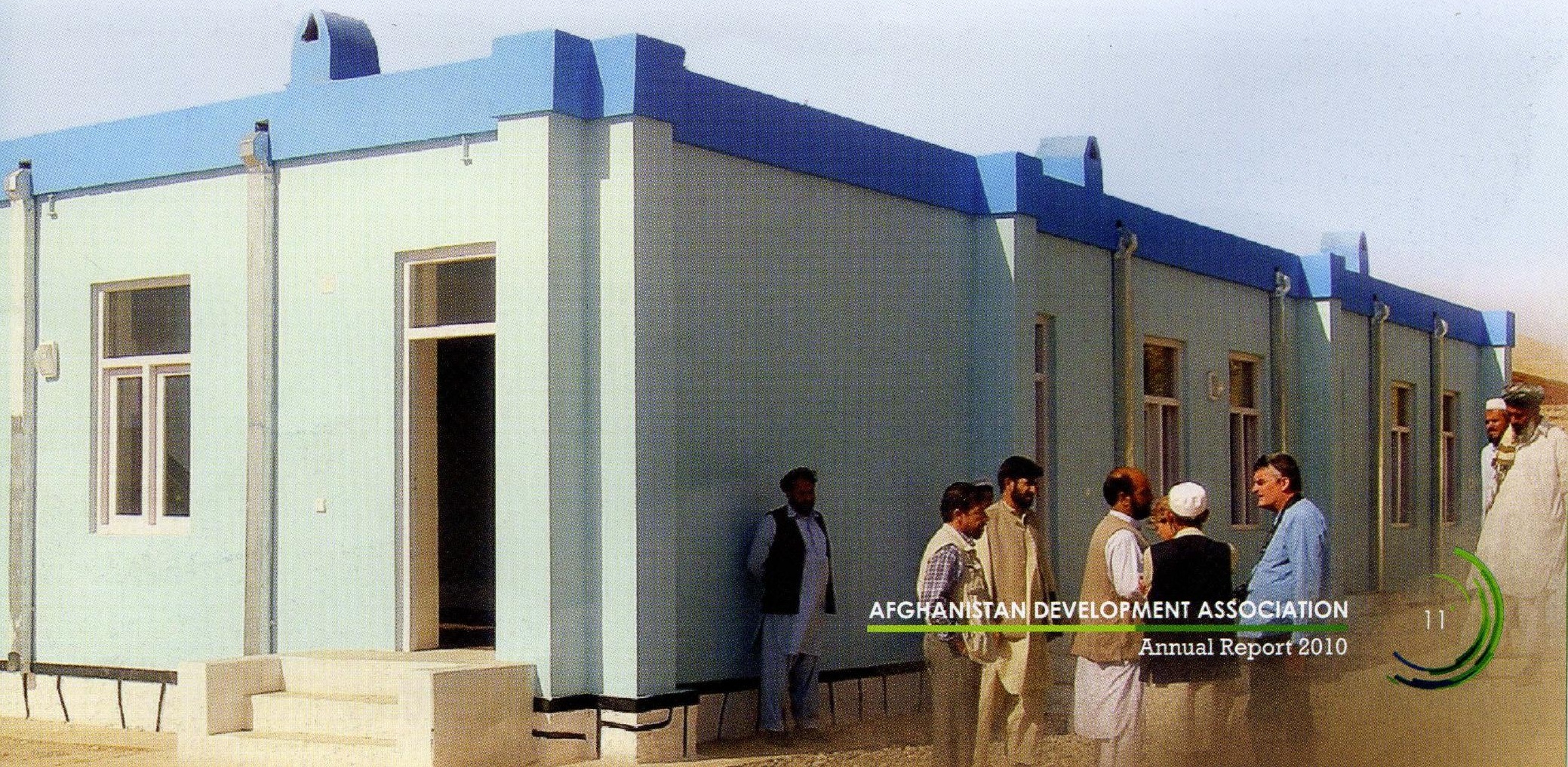




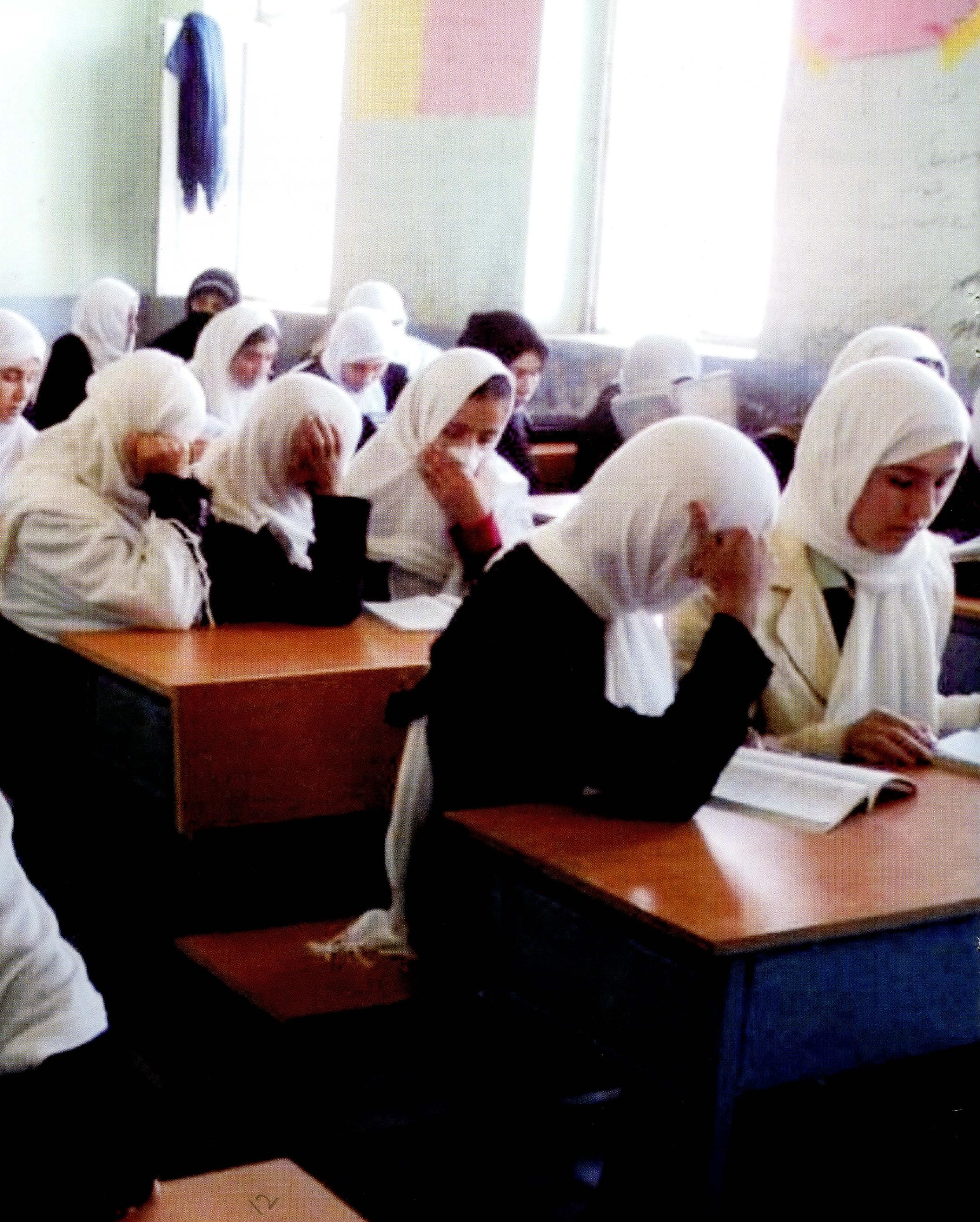




\section{TAKHAR PROVINCE}

2010 Services

\section{Beneficiaries}

Total: 11 Schools

(1) 16483 Students, 109 Teachers

2950 Students, 13 Teachers

3460 Students, 15 Teachers

\section{Facilities \& Distribution;}

(1) 3798 Benches \& Desks for students

183 Desk/Chairs for teacher

57 Blackboard

20 Bookshelf

256 m2 Carpet

7 Sofa set

(2) 270 Benches \& Desks for students

15 Desk/Chairs for teacher

10 Blackboard

3 Bookshelf

40 m2 Carpet

1 Sofa Set

3230 Benches \& Desks for students

16 Desk/Chairs for teacher

10 Blackboard

2 Bookshelf

30 m2 Carpet

\section{Activities:}

Project Mobilization, Survey, Proposal

Development, Supervision \& Monitoring

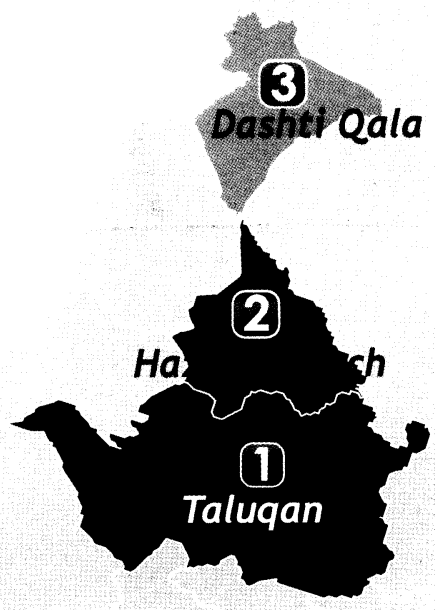




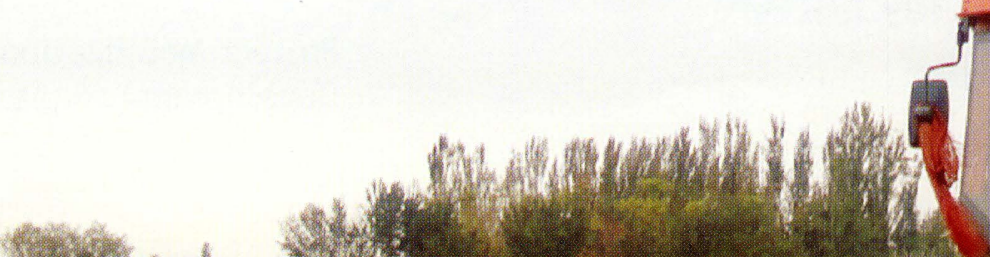
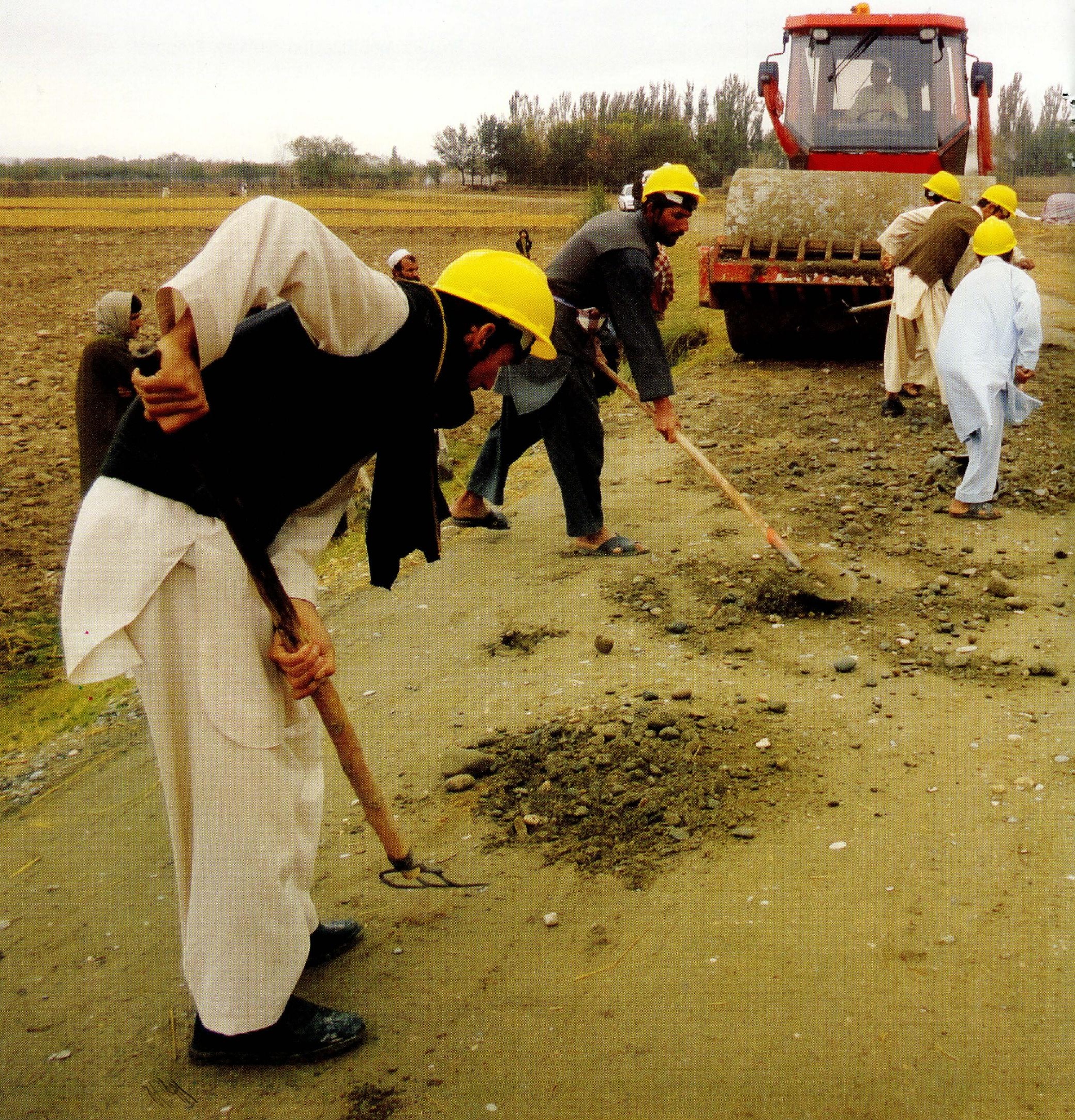


\section{KUNDUZ}

2010 Services

\section{Beneficiaries}
(1) 10000 Patients
(2) 1000 Families
(3) 14400 Families
415000 Culverts Contraction

\section{Facilities \& Distribution;}
11 Clinic Waiting hall construction
22 Aqueducts Contraction
33 Culverts Contraction
600 Benches \& Desks for students
60 Desk/Chairs for teacher
80 Blackboard
16 Bookshelf
$350 \mathrm{~m} 2$ Carpet

Q 2 Culverts Contraction

\section{Activities:}

Project Mobilization, Survey, Proposal Development, Supervision \& Monitoring

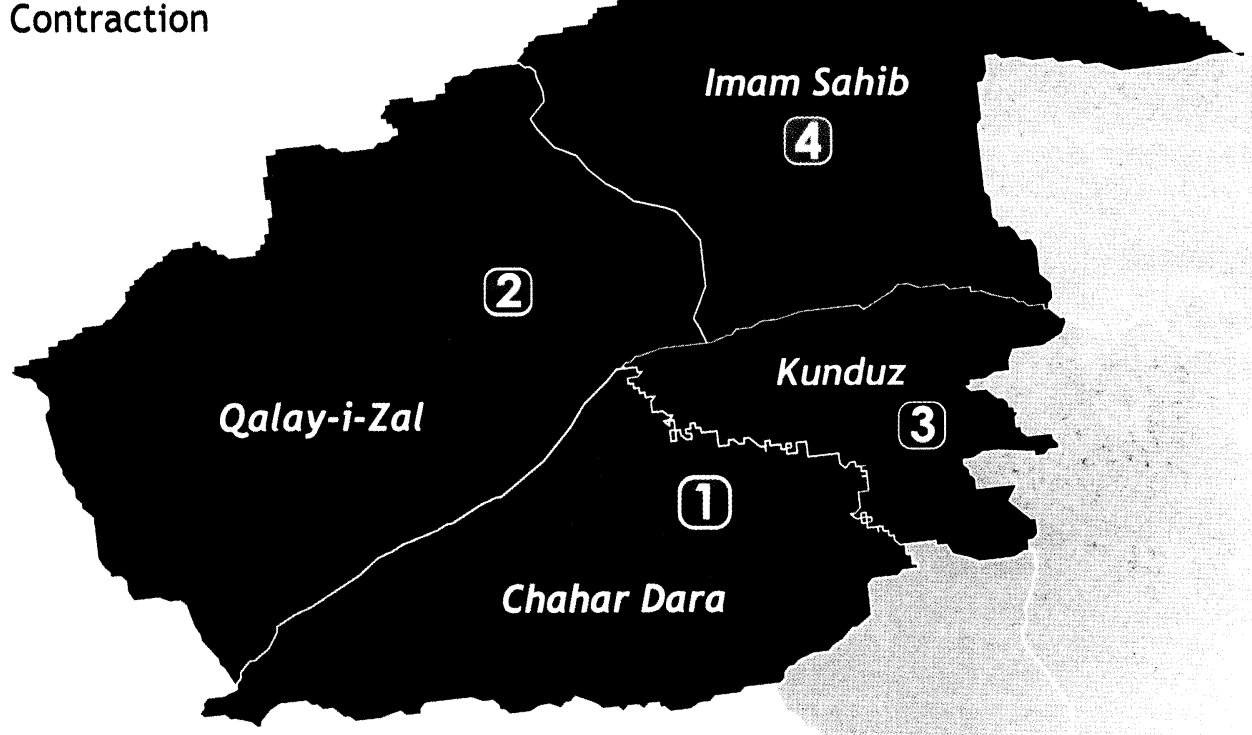




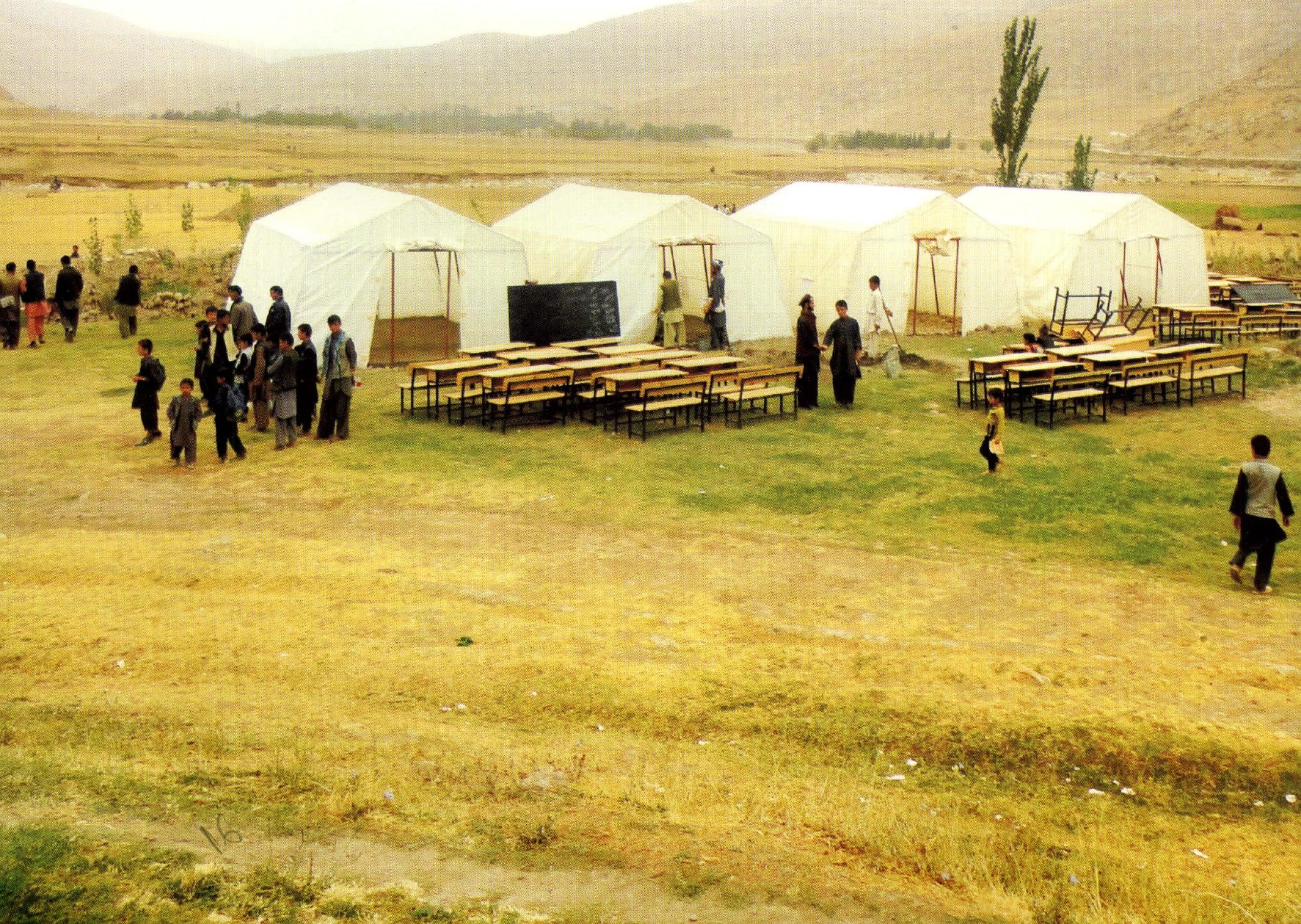


BADAKHSHAN

2010 Services

Beneficiaries

Total: 8 Schools, 60 Familys

12483 Students, 81 Teachers

2600 Students, 8 Teachers

3800 Students, 30 Teachers

4100 Families

Facilities \& Distribution;

11241 Benches \& Desks for students

156 Desk/Chairs for teacher

87 Blackboard

10 Bookshelf

144 m2 Carpet

1 Sofa set

4100 Solar Panel Distributed

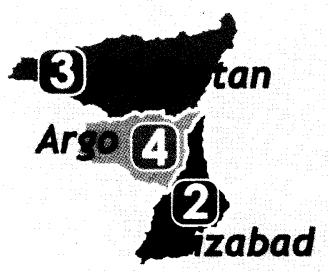

\section{Facilities \& Distribution;}

(2) 300 Benches \& Desks for students

12 Desk/Chairs for teacher

7 Blackboard

3 Bookshelf

46 m2 Carpet

4 Temporary Shelter

3200 Benches \& Desks for students

10 Desk/Chairs for teacher

8 Blackboard

2 Bookshelf

35 m2 Carpet

10 Tent

\section{Activities:}

Project Mobilization, Survey, Proposal Development, Supervision \& Monitoring 


\section{辣}

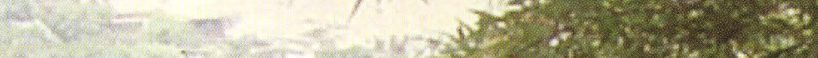

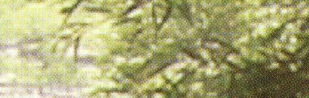

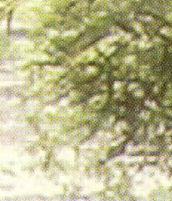

ind

$2 x^{2}-3 x^{2}$

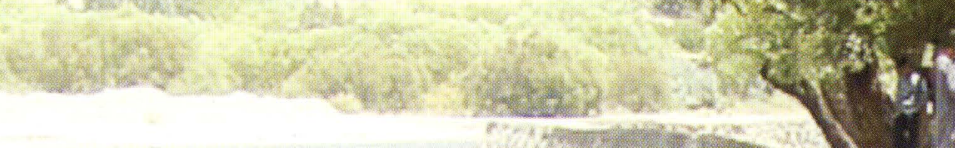

ses.

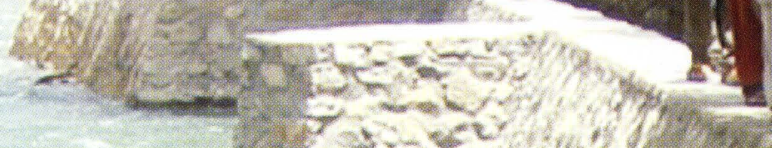

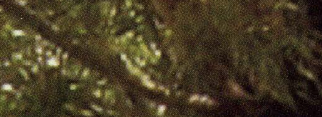

2. 3

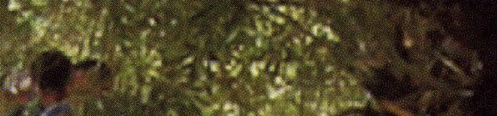

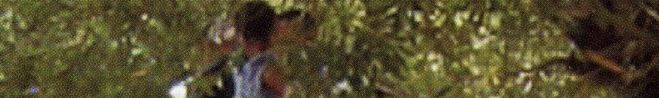
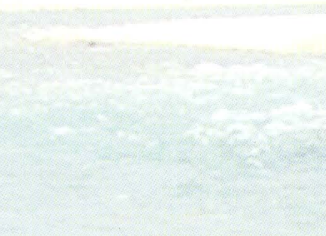

usiat

-

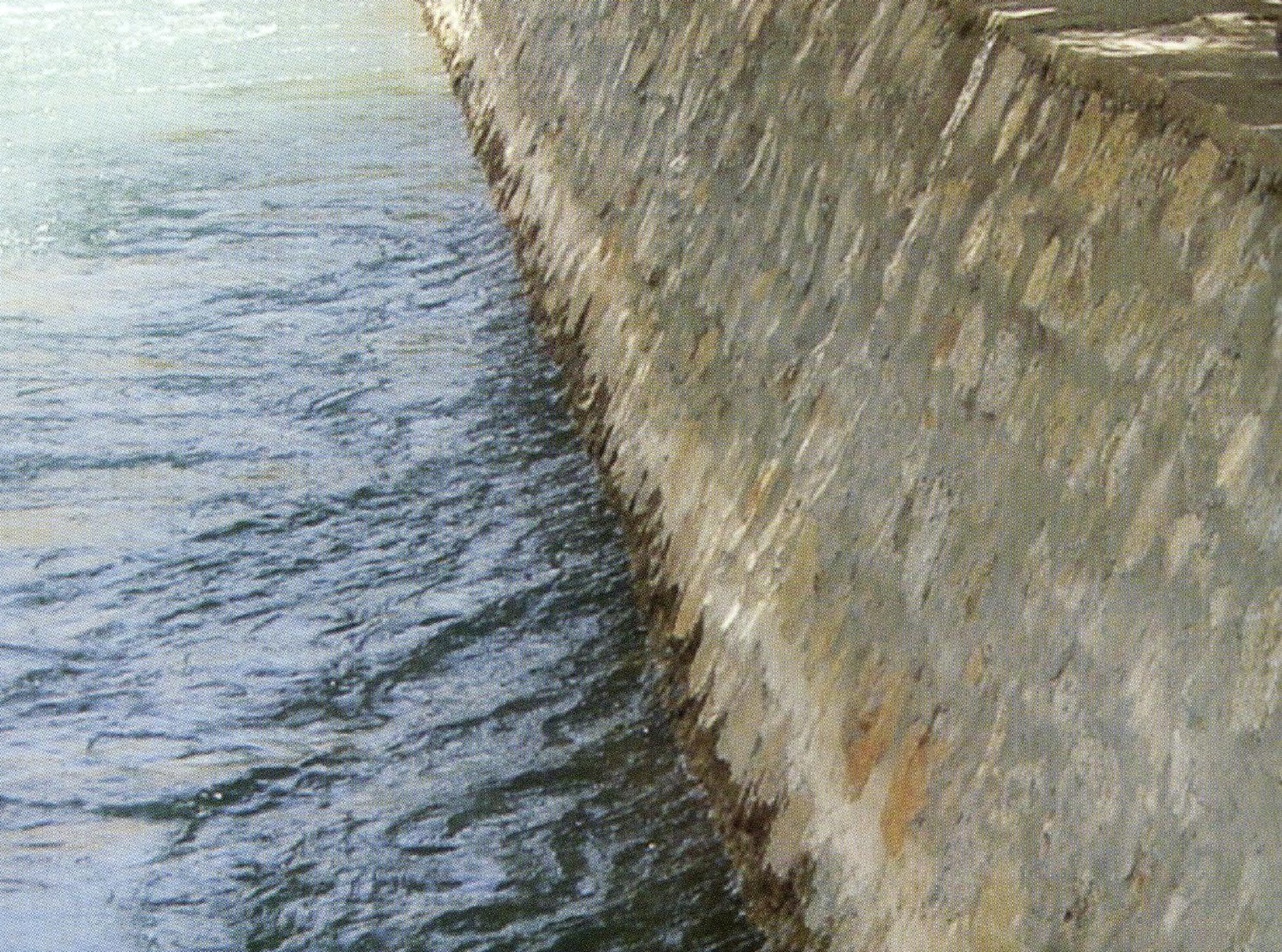




\section{PANJSHER PROVINCE \\ 2010 Services}

Beneficiaries
1800 Families
(2) 2700 Families

Facilities \& Distribution;

1 Irrigation Canal,

(2) Retaining Wall Construction

\section{Activities:}

Project Mobilization, Survey, Proposal Development, Supervision \& Monitoring

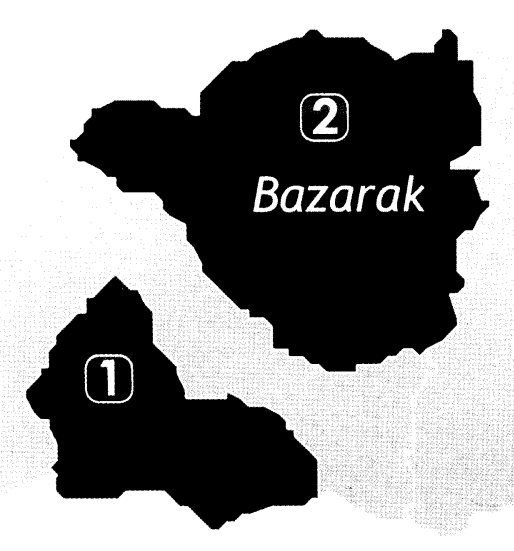




\section{EXPENDITURE FOR THE YEAR - 2010 CAPACITY BUILDING DEPARTMENT}

Total Budget: $\quad \$ 1,053,824.00 \quad$ Afg $49,529,728.00$ $57 \%$

Novib

Donor

Novib

Community Based Disaster Risk Reduction (Phase II)

Community Based Disaster Risk Reduction (Phase III)

USAID/CAII - CBSG

Community Based Stabilization Grants (CBSG)

\section{CARE International}

On Job Training Beautician \& Bag Making (VTAWP)

Beautician \& Bag Making (VTAWP)

On Job Training Beautician \& Bag Making (VTAWP) P II

VTAWP - Business Development Officer (BDO)/Assistant

Beautician, Bag Making and Charmadozi - (VTAWP) P III

Emergency Disaster Preparedness \& Response for Afg (EDPRA)

CSAR \& IDPs Bags and Tailoring Trainings

Business Marketing Entrepreneurship and Life Extra Skills

\section{Church World Services (CWS)}

Enhancement in Enrolment \& Retention of Girls \&

Quality Education - PII

Enhancement in Enrolment \& Retention of Girls \&

Quality Education

\section{Christian Aid (CA)}

Beautician and Bag Making (VTAWP)

Community Right Mobilization and Response

\section{Other}

The of Climate Change and Food Insecurity on Poverty Community discussions on Civilian Casualties

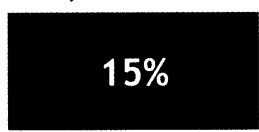

USAID/CAII

Duration
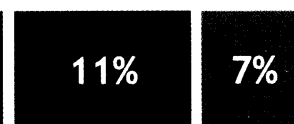

$6 \% 4 \%$

CARE

CWS CA Other

Total

Project Budget Satus

Jun 09 - Jun $10 \quad \$ 139405$

Completed

Sep 10 - Aug $11 \quad \$ 162464$

Completed

$\operatorname{Mar} 10-\operatorname{Dec} 11 \$ 162464$

Ongoing

$\begin{array}{lll}\text { Mar 10 - Apr 10 } & \$ 12097 & \text { Completed } \\ \text { Feb10 - Jun10 } & \$ 51494 & \text { Completed } \\ \text { May 10 - Jun 10 } & \$ 14420 & \text { Completed } \\ \text { Mar 09 - Feb 10 } & \$ 9840 & \text { Completed } \\ \text { Jun 09 - Feb 10 } & \$ 76664 & \text { Completed } \\ \text { May 09 - Aug 10 } & \$ 27650 & \text { Completed } \\ \text { Nov 09 - Dec 10 } & \$ 653560 & \text { Completed } \\ \text { Nov 10 - Mar 11 } & \$ 38293 & \text { Completed }\end{array}$

Feb 10 - Jun $10 \quad \$ 162464 \quad$ Completed

Feb 10 - Jun $10 \quad \$ 162464 \quad$ Completed

Feb 10 - Jun $10 \quad \$ 162464 \quad$ Completed

Sep 10 - Aug $11 \$ 76530 \quad$ Completed

Apr 10 - Jan $11 \$ 10465 \quad$ Completed

Oct 10 - Nov $11 \$ 78146 \quad$ Ongoing

AFGHANISTAN DEVELOPMENT ASSOCIATION

Annual Report 2010 


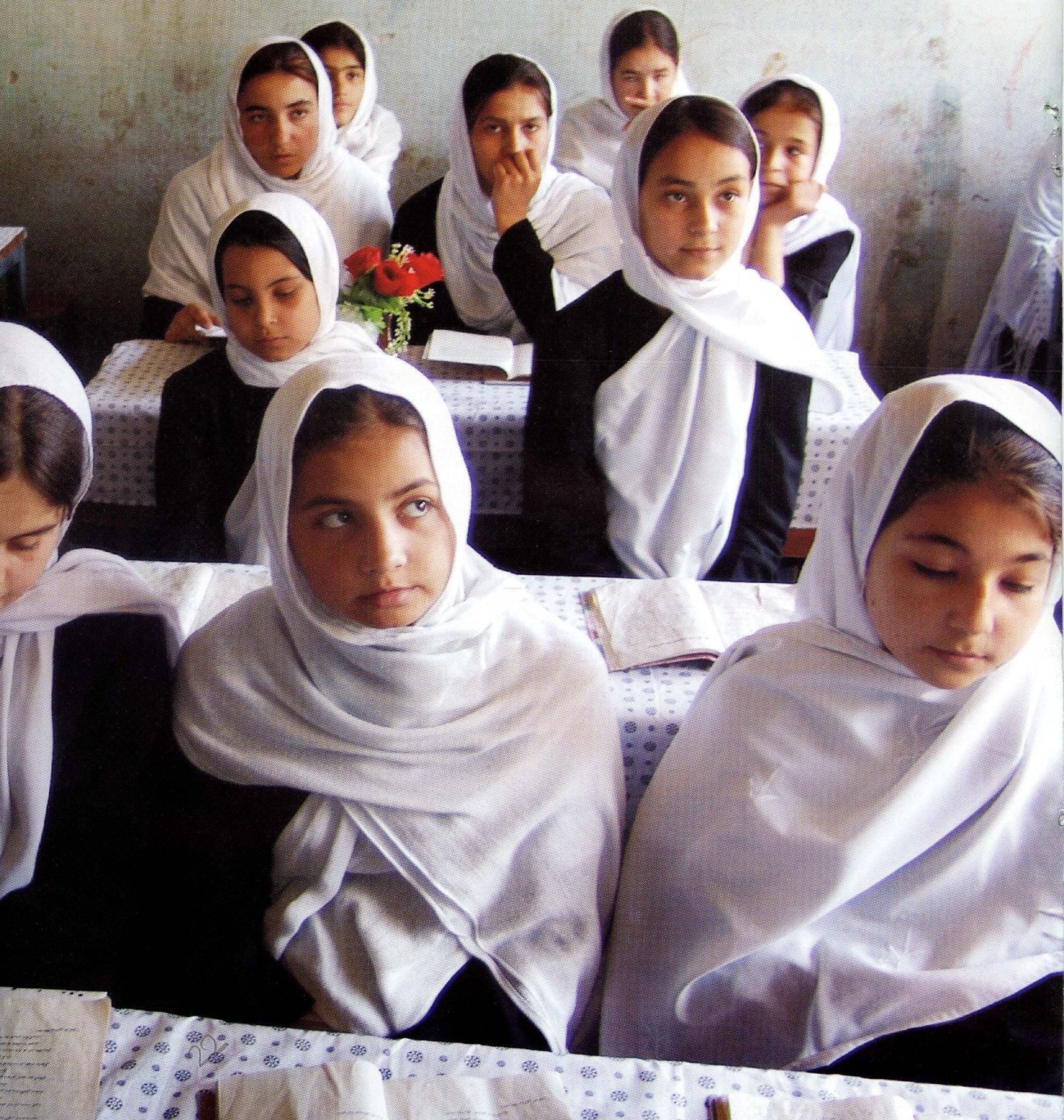


provided the facility and learning opportunity for 250 girls and boys whose ages were between 10 and 13 years and they were not allowed to be enrolled in official schools of the Ministry of Education (MoE) in some areas of the country. Subsequently, after the successful implementation of the projects in Qaramqol district of Faryab Province for the time being, the focal students have been enrolled in MoE formal schools for continuation of their upgrading education, which will definitely enable them to meet the new techniques and development values of education accordingly.
It also helped some rural villages in Tirinkot provincial capital of Uruzgan province through provision of quality solar panels to the right holders to whom electrification facilities for studying school subjects, writing homework, training, and media related visions were provided during the last four years. finally, the fourth phase of electrification of rural villages project has been successfully completed during the period of 13 months starting from January 2010 to Jan 2011

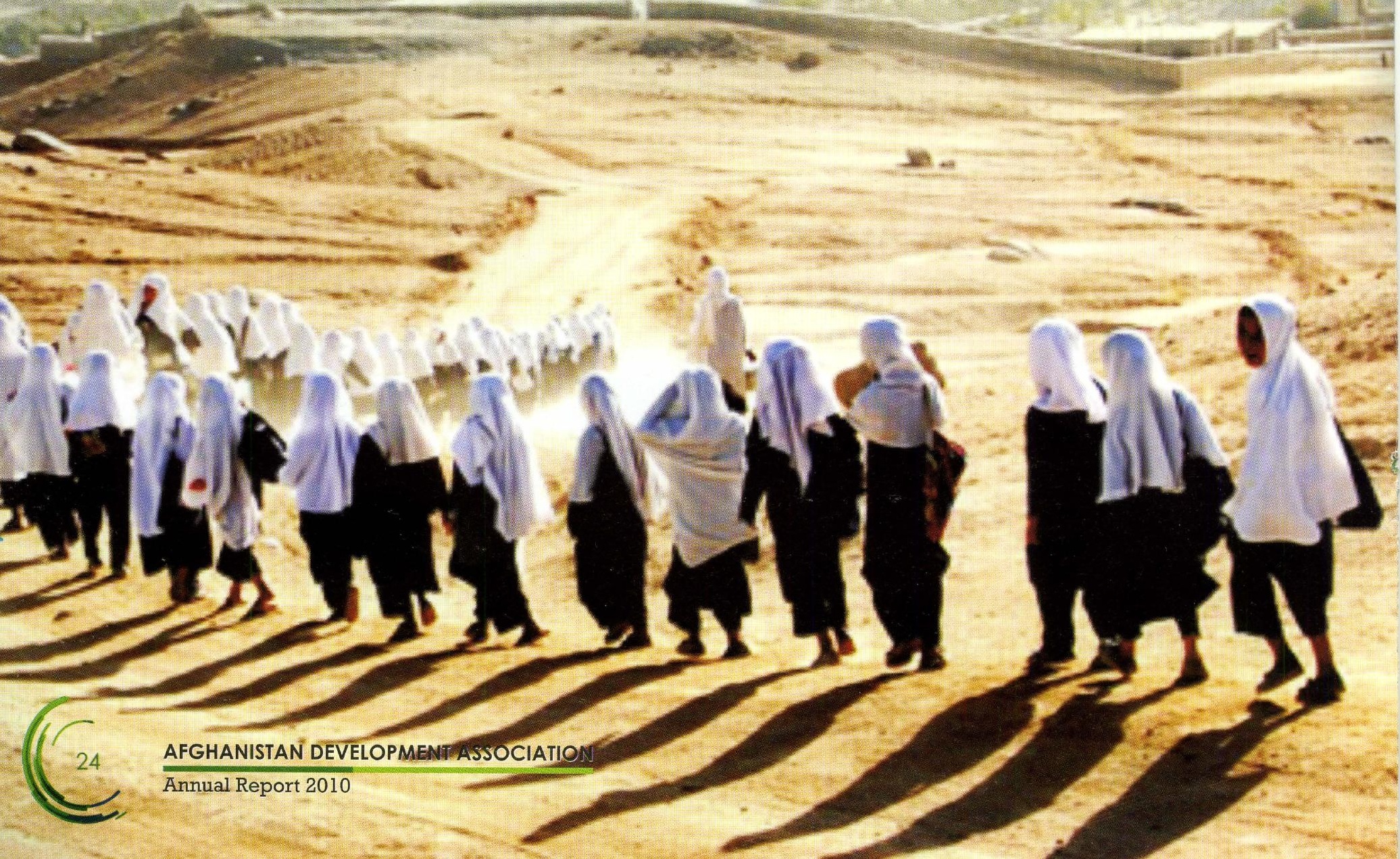




\section{WOMEN EMPOWERMENT - BASIC LITERACY}

Duration: 1 JAN 2010 - 31 Dec 2010

\section{Community Role:}

Providing space for self help group center, Introducing trainers, Monitoring of Project, Solve any problem during implementation of the project

\section{Stakeholders:}

Provincial education and district education departments at provincial level, District Development Assembly (DDA) and the related community

Deputy Ministry of Literacy in center level

\section{Facilities / Distributions:}

Classrooms, Teachers \& Students' Kits

\section{Beneficiaries:}

250 Over age children (125 Female, 125 Male) whose ages are $b / w 10-13$ years

100 Teacher

\section{Result / Achievement:}

- 10 Teachers for literacy classes are selected, trained \& taught in 10 literacy classes

- 250 girls \& boys completed the literacy curricula, enrolled in grade four in the formal schools

- 250 girls \& boys are able to help their brothers \& sisters with their school lessons

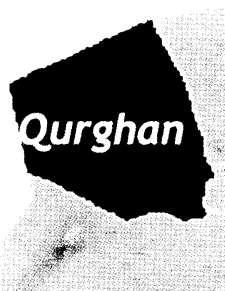

FARYAB

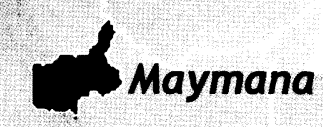




\section{$0^{0}$}




\section{WOMEN EMPOWERMENT - ECONOMICS}

Duration: 1 JAN 2010 - 31 Dec 2010

\section{Community Role:}

Providing space for self help group center, Introducing trainers, Monitoring of Project, Solve any problem during implementation of the project

\section{Stakeholders:}

Provincial education and district education departments at provincial level, District Development Assembly (DDA) and the related community

Deputy Ministry of Literacy in center level

\section{Facilities / Distributions:}

Wool, Loom \& mask \& Kits for trainees

\section{Beneficiaries:}

100 Poor Women

5 Trainers

\section{Result / Achievement:}

- 100 Women selected $\&$ trained in cross cutting issue who also received functional literacy

- 5 self-help groups consisting of 100 women established and functioned

- 5 self-hlep groups' members received micros credit

- 37 previous self-help groups consisting of 740 women

further trained, supported and followed up

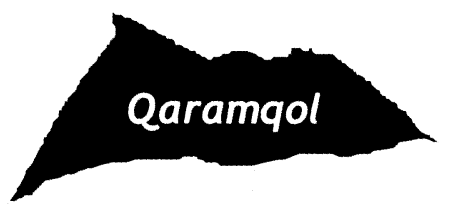

FARYAB Maymana 


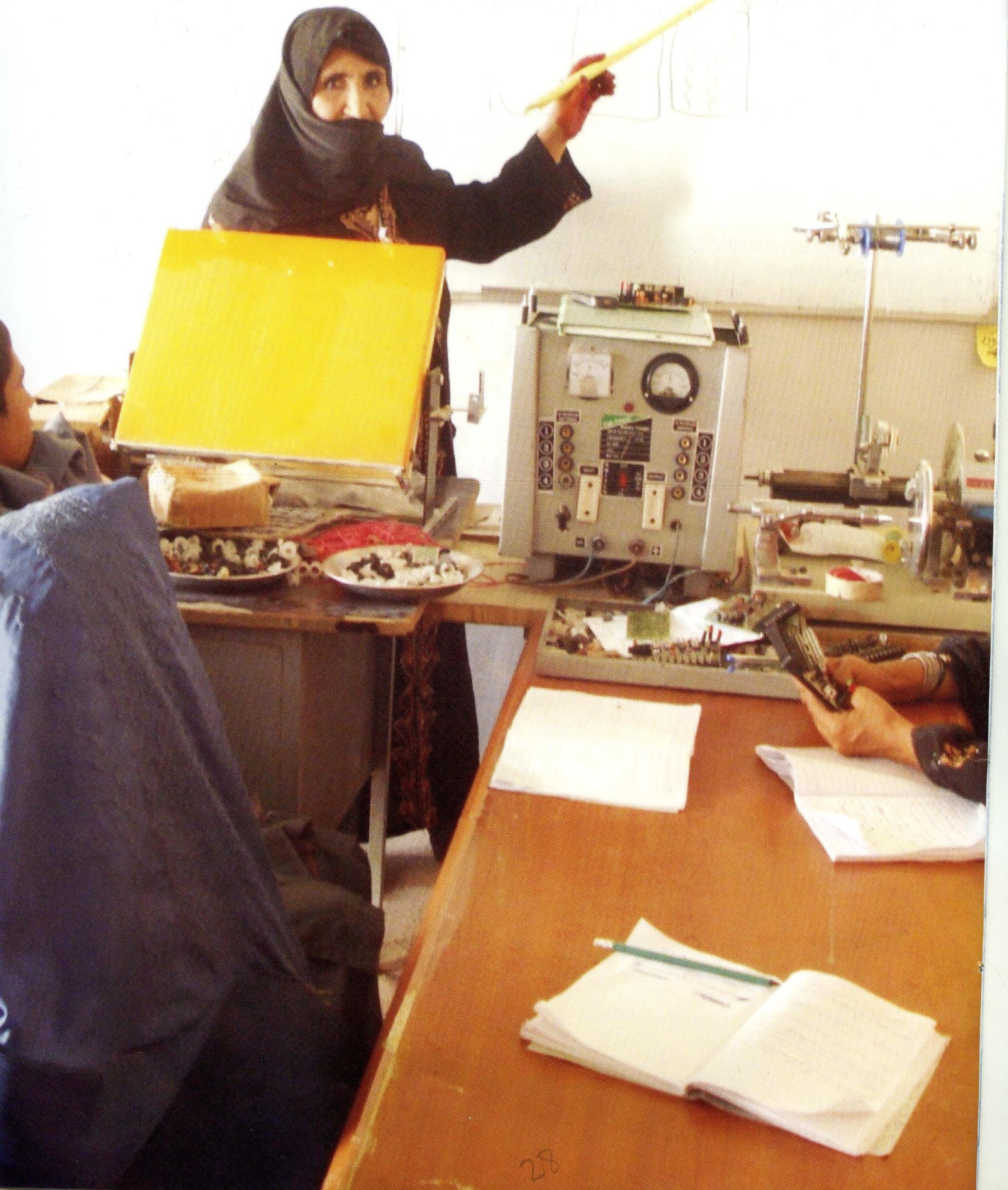




\section{CLIMATE CHANGE MITIGATION}

Duration: 1 Jan 2010 - 31 Jan 2011

\section{Community Role:}

Providing space for solar electrification workshops, introducing trainees, providing salary of trainees, Transportation of solar panels to their villages and monitoring of the project.

\section{Stakeholders:}

Governor of Uruzgan, MRRD, MoEC provincial departments, Community Development Council (CDCs) \& related communities

\section{Facilities / Distributions:}

Equipment of solar workshops for practical work during training \& Trainees' kit (solar electrification workshop equipments)

\section{Beneficiaries}

Trainees: 8 Trainer: $2 \quad$ Families: 1,000

\section{Result / Achievement:}

- 1000 solar panels installed in 1000 household in the selected villages

- Eight persons selected \& trained as solar engineers

- Four solar electrification workshop established and functioning in the target villages

\section{URUZGAN}

Chora

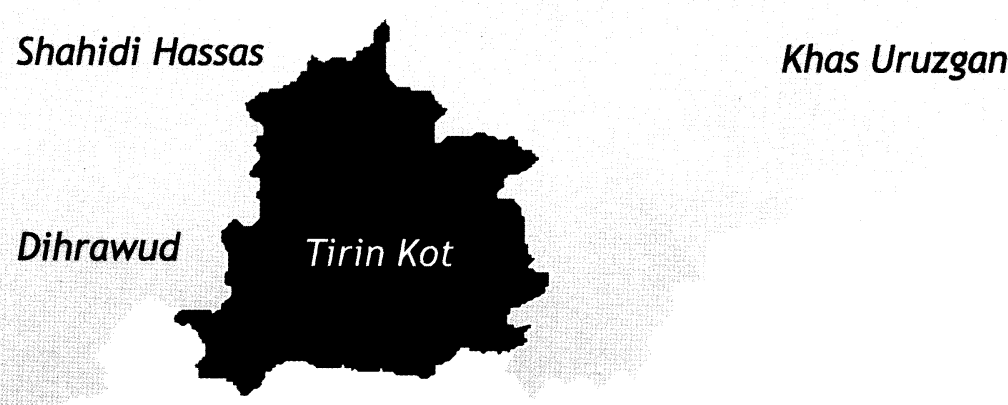




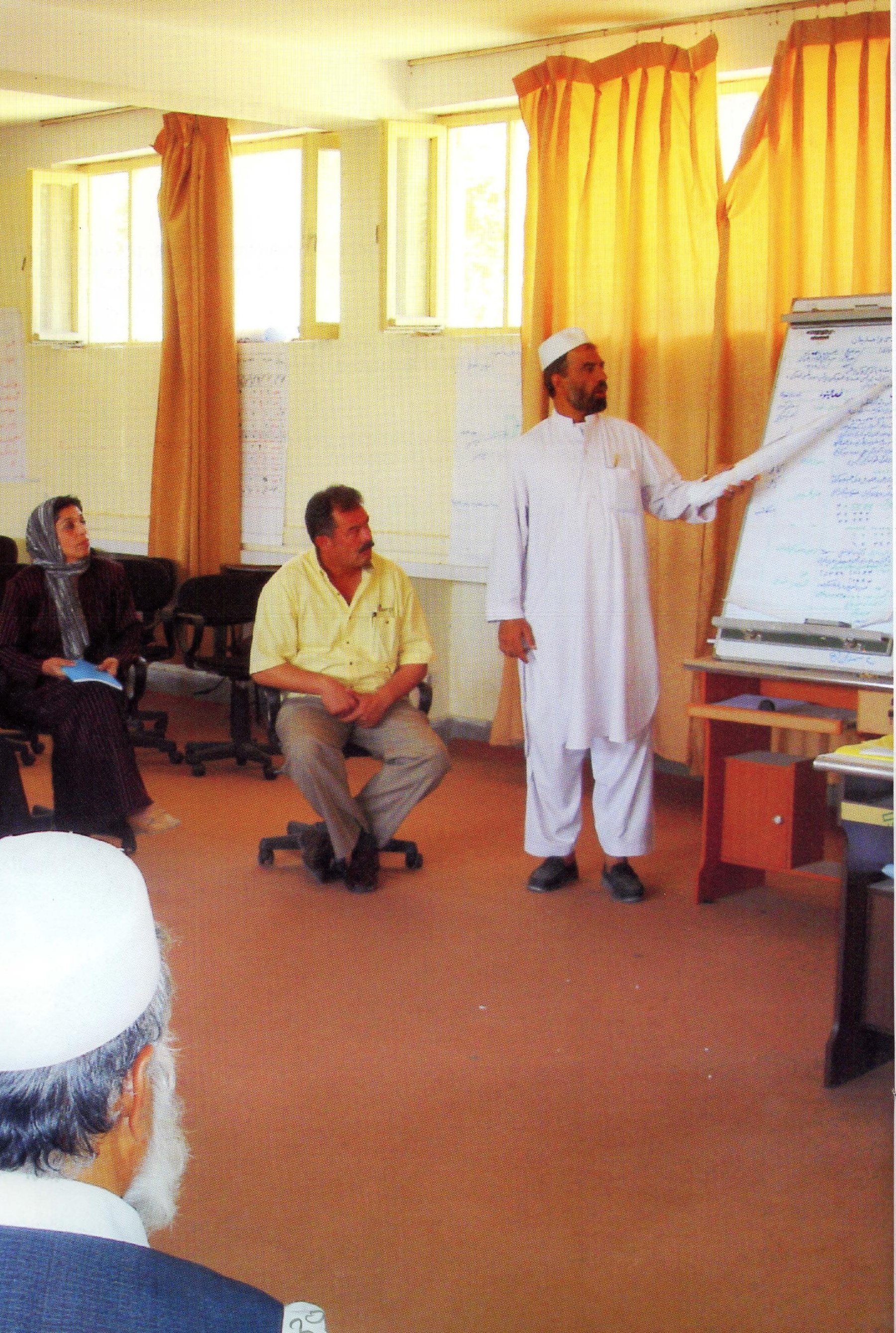




\section{BUILDING EDUCATION SUPPORT SYSTEM FOR TEACHERS (BESST)}

Duration: 23 Apr 2008 - 31 May 2011

\section{Community Role:}

Participate in School development council (SDC), prioritize their schools' problems \& finding resources for solving their schools' problems, protecting their schools, and support their schools in attendance of students.

\section{Stakeholders:}

MoE and Teacher Education Directorate (TED) at the central level, Provincial Education Department (PED) as the provincial level, District Education Departments (DEDs), principles of schools, head masters and teachers, School Development Council (SDCs) at district level.

\section{Facilities / Distributions:}

INSET-I \& I| training study materials and trainers' Guides, School management trainers' manuals, In-school Teachers Support Activities (ITSA) Manuals.

\section{Beneficiaries:}

Trainers: 246

Teachers: 13,200

Principles: 510

\section{Result / Achievement:}

- 13,200 formal schools' teachers received INSET-I \& || trainings

- 520 Teacher Learning Circles (TLCs) established \& functioning

- 150 Principles Learning Circles (PLCs) established \& functioning

- 385 School Development Council (SDCs) established \& functioning

- 510 Principle received two school management training

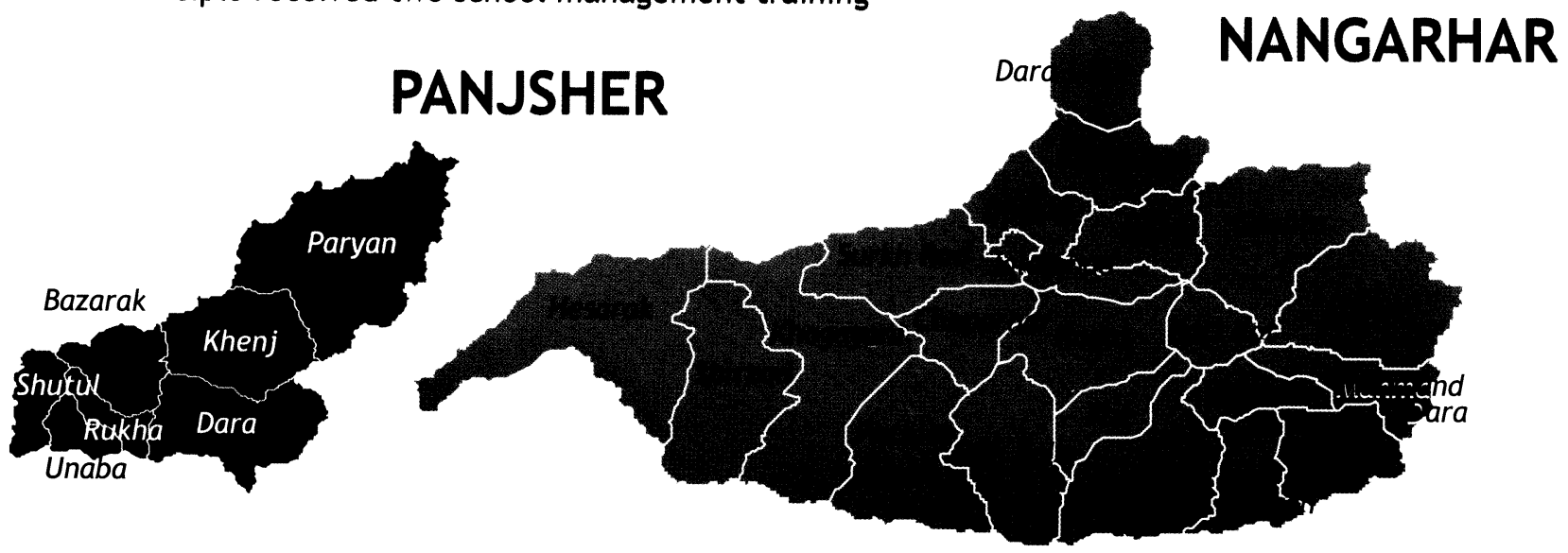



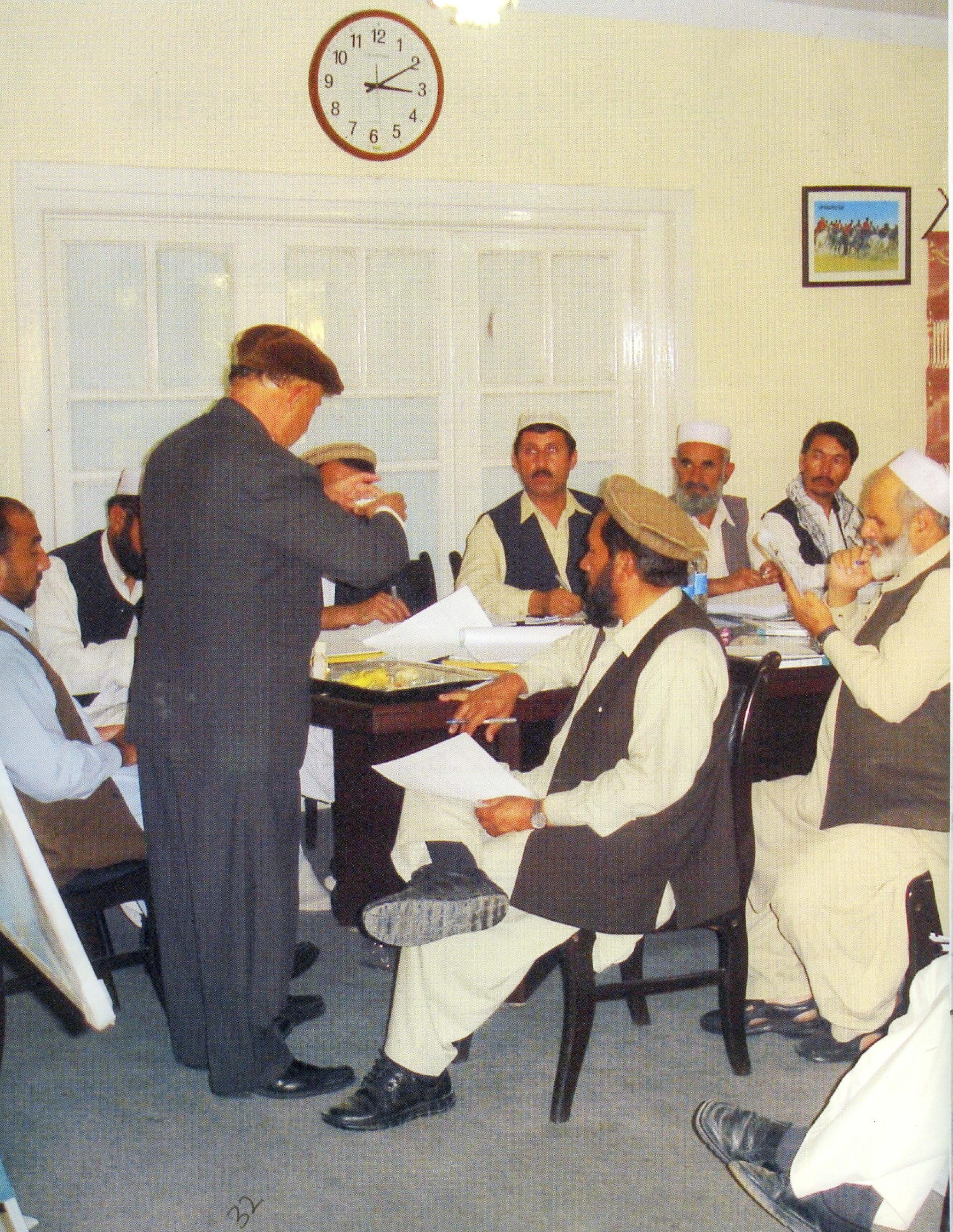


\section{EDUCATION QUALITY IMPROVEMENT PROGRAM (EQUIP-II)}

Duration: 1 Jan 2009 - 31 Jul 2012

\section{Community Role:}

Participate in School development council (SDC), prioritize their schools' problems \& finding resources for solving their schools' problems, protecting their schools, and support their schools in attendance of students.

\section{Stakeholders:}

Ministry of Education and Teacher Education Directorate (TED) at the central level, Provincial Education Departments (PEDs) at the provincial level, District Education Departments (DEDs), principles, head masters and teachers, School Development Council (SDCs) at district level.

\section{Facilities / Distributions:}

INSET-I \& II training study materials and trainers' guides, School management trainers' manuals, In-school Teachers Support Activities (ITSA) Manuals

\section{Beneficiaries}

Trainers: 1,260 Teacher: 45,000 Principles: 3,200

\section{Result / Achievement:}

- 41,911 Teachers have received INSET-I training

- 11,441 Teachers have received INSET-II I training

- 3,174 Principles have received first School management training

- 1,110 Principles have received second school management training

- 811 Teachers learning circles established and functioning

- 221 Principles learning circles established and functioning

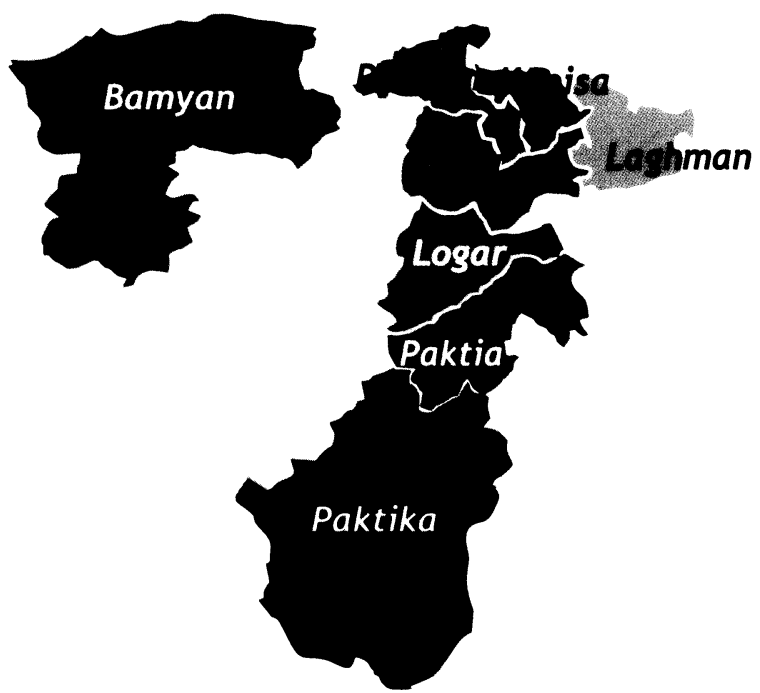




\section{Achievements}

Training: The following teachers received INSET-I training during the year 2010:

\begin{tabular}{|c|c|c|c|c|c|c|c|c|}
\hline \multirow{2}{*}{ No } & \multirow[t]{2}{*}{ Province } & \multirow[t]{2}{*}{ Target } & \multicolumn{3}{|l|}{ Planed } & \multicolumn{3}{|c|}{ Completed } \\
\hline & & & Female & Male & Total & Female & Male & Total \\
\hline 01 & Kabul & 19,477 & 12,572 & 7,766 & 20,338 & 12,629 & 6,874 & 19,503 \\
\hline 01 & Parwan & 5,784 & 593 & 4,324 & 4,917 & 715 & 4,946 & 5,661 \\
\hline 01 & Kapisa & 2,780 & 387 & 2,500 & 2,887 & 357 & 2,364 & 2,721 \\
\hline 01 & Laghman & 3,434 & 189 & 3,156 & 3,345 & 218 & 3,294 & 3,512 \\
\hline 01 & Logar & 2,457 & 333 & 2,173 & 2,506 & 345 & 2,172 & 2,517 \\
\hline 01 & Bamyan & 3,064 & 531 & 2,441 & 2,972 & 636 & 2,430 & 3,066 \\
\hline 01 & Paktia & 4,544 & 90 & 3,124 & 3,214 & 144 & 2,092 & 2,236 \\
\hline 01 & Paktika & 3,460 & 204 & 3,124 & 3,051 & 113 & 2,582 & 2,695 \\
\hline & TOTAL & 45,000 & 14,899 & 28,331 & 43,230 & 15,157 & 26,754 & 41,911 \\
\hline
\end{tabular}

The following number of principals, deputies, head masters and school heads received school management training during the year 2010 :

\begin{tabular}{|c|c|c|c|c|c|c|c|c|}
\hline \multirow{2}{*}{ No } & \multirow[t]{2}{*}{ Province } & \multirow[t]{2}{*}{ Target } & \multicolumn{3}{|l|}{ Planed } & \multicolumn{3}{|c|}{ Completed } \\
\hline & & & Female & Male & Total & Female & Male & Total \\
\hline 01 & Kabul & 954 & 192 & 762 & 954 & 146 & 631 & 777 \\
\hline 01 & Parwan & 353 & 9 & 344 & 353 & 12 & 335 & 5,661 \\
\hline 01 & Kapisa & 267 & 21 & 248 & 269 & 17 & 256 & 347 \\
\hline 01 & Laghman & 314 & 15 & 299 & 314 & $\underline{0}$ & 302 & 302 \\
\hline 01 & Logar & 252 & 12 & 238 & 250 & 35 & 277 & 312 \\
\hline 01 & Bamyan & 423 & 30 & 393 & 423 & 31 & 390 & 421 \\
\hline 01 & Paktia & 165 & 2 & 163 & 165 & 1 & 161 & 162 \\
\hline \multirow[t]{2}{*}{01} & Paktika & 472 & 14 & 459 & 473 & 7 & 432 & 439 \\
\hline & TOTAL & 3,200 & 295 & 2,906 & 3,201 & 249 & 2,784 & 3,033 \\
\hline
\end{tabular}




\section{EXPENDITURE FOR THE YEAR - 2010 EDUCATION DEPARTMENT}

Total Budget: $\quad \$ 8,144,298.00 \quad$ Afg $382,782,006.00$

$73.7 \%$

MoE

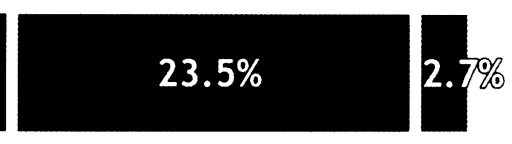

USAID/CAII-CBSG NCA

Donor

Total

Donor

Duration

Project Budget

Satus

\section{Ministry of Education}

Consulting Services for District Teachers Training

Programme (CSDTTP)

$$
\text { Jan } 09 \text { - Aug } 12
$$

$\$ 19645300$ Ongoing

\section{USAID/CAII - BESST}

Building Education Supporting System for Teacher (BESST)

\section{Norwegian Church Aid (NCA)}

Women Empowerment - Basic Literacy - Phase IV

Jan 10 - Dec 10

$\$ 53249$ Completed

Women Empowerment - Women \& Economics - Phase II

Jan 10 - Dec 10

$\$ 138728$ Completed

Environment \& Renewable Energy - Solar Electrification of Rural Villages - Phase IV

May 10 - Jun 10

$\$ 39688$ Completed 


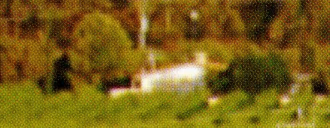

a.peशmis

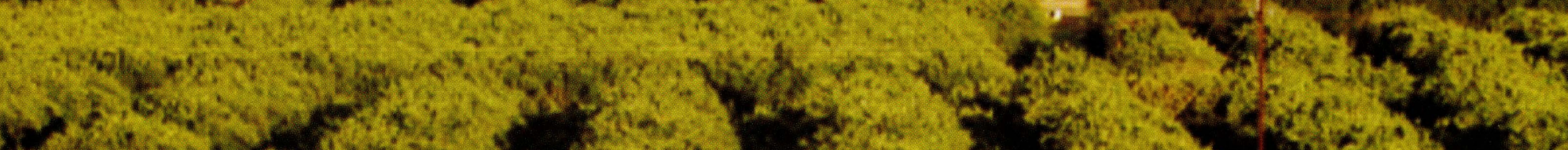
(5)

in?

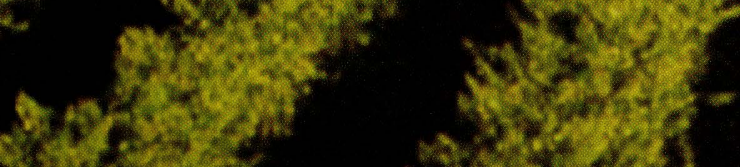

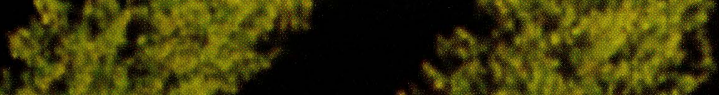

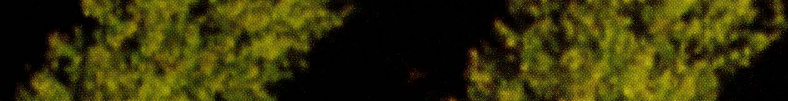

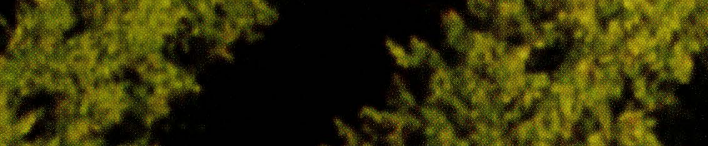
(2)

$2^{2}+3 \times 5 \times 23$

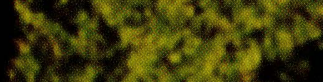

$-4 x^{2} x^{3}+3 x^{2}$

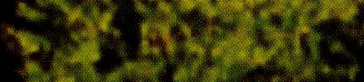

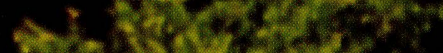

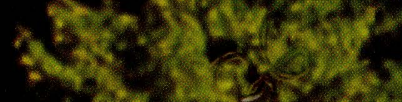

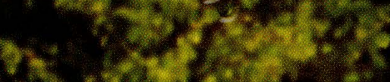

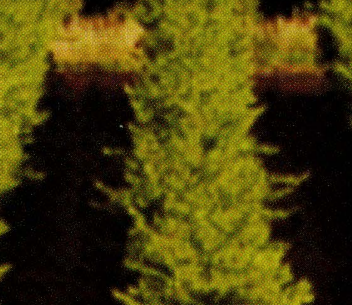

$x^{2}-303$ $x^{2}+x^{3}+2$ $+x^{2}=2$

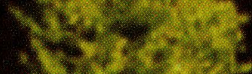
$x^{2}+x^{2}+23$ $+2 x^{4}+x^{2}+2$ $+2 x^{2}+3$ $-6 x^{3}+r^{2}: 3$

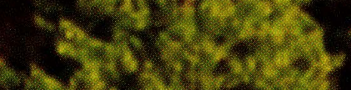
$4 \times 3 \times 3: 250$ $+4860,36$ $2-2 x^{2} y^{2}-3+26$

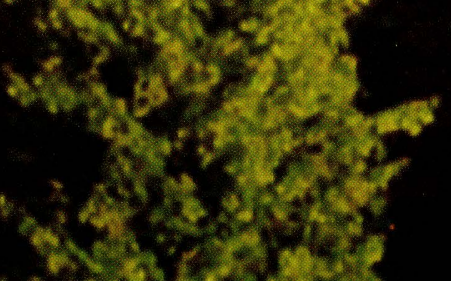

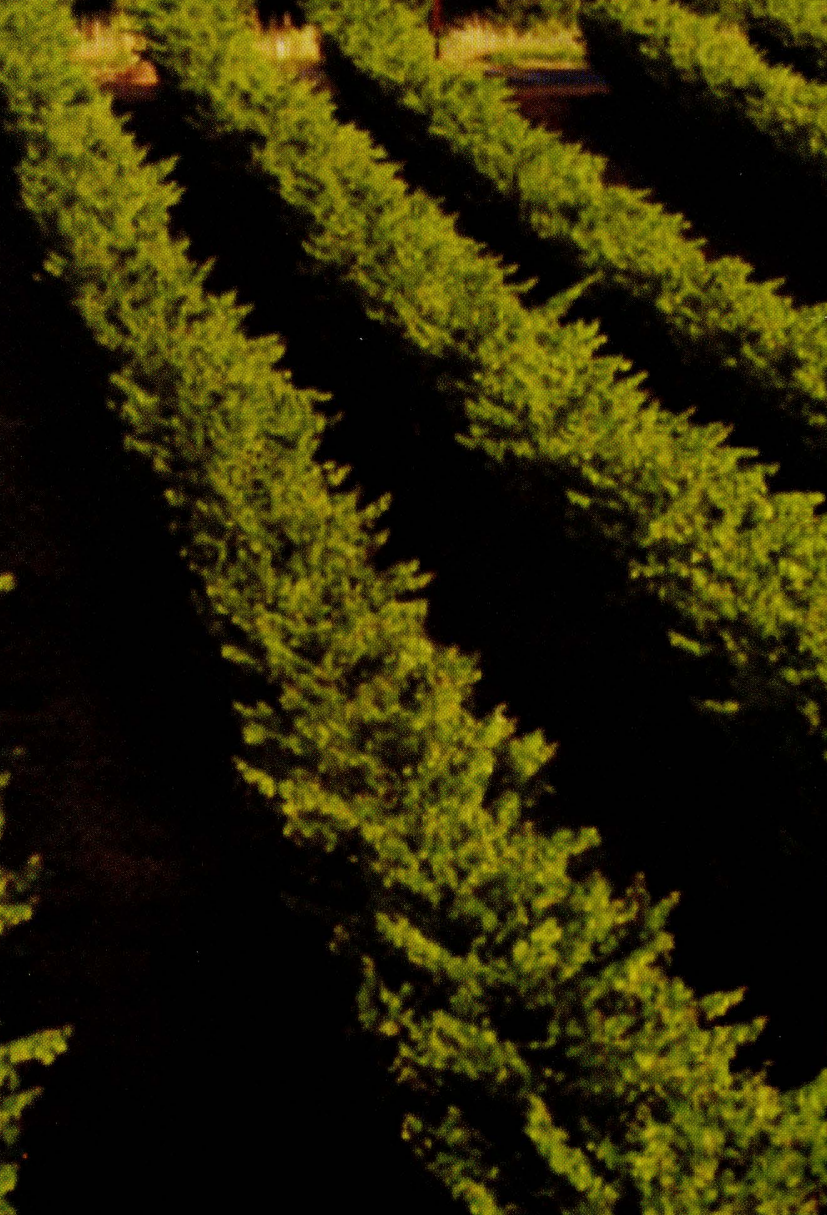




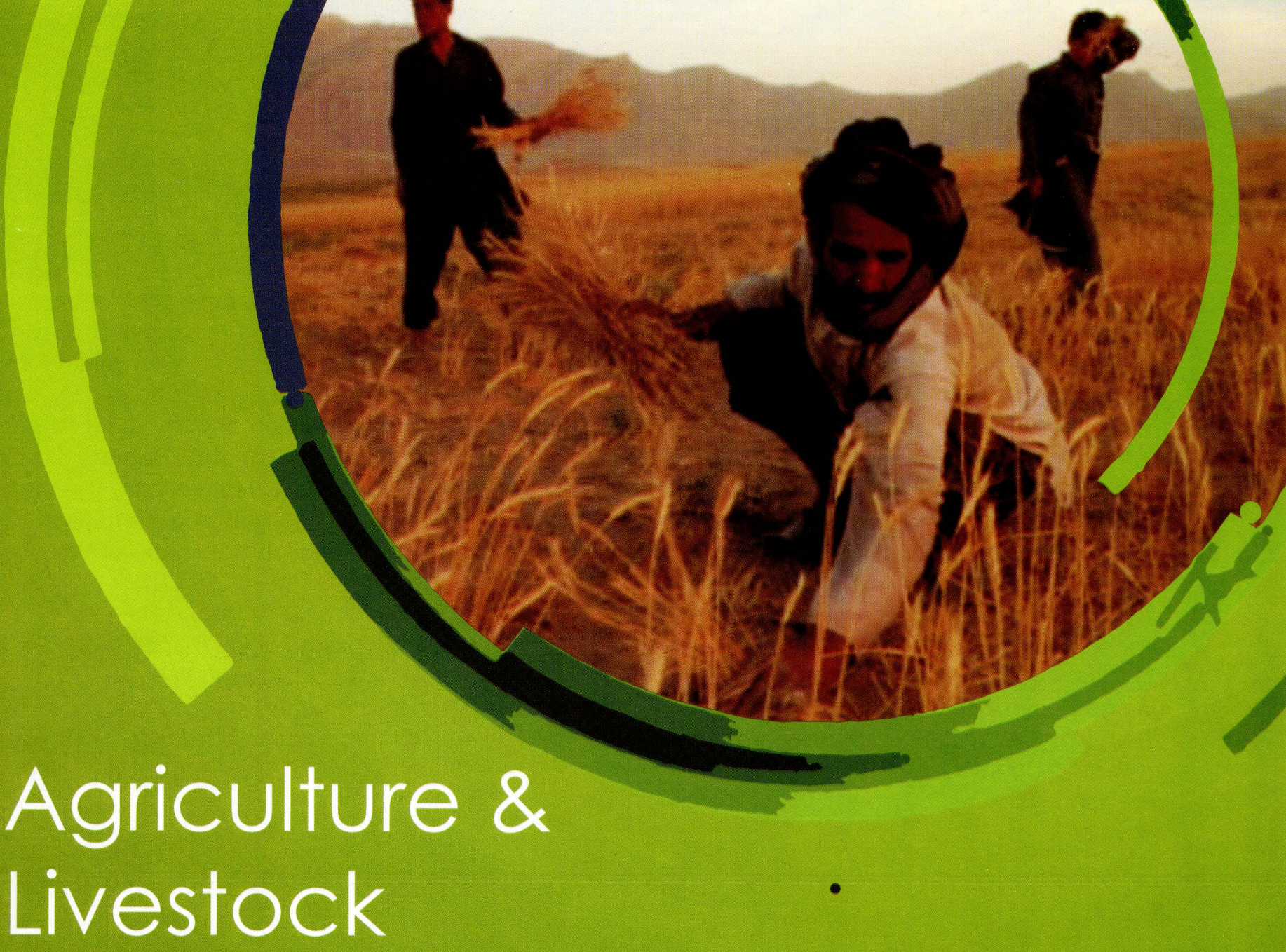

\section{Reflections From 2010}

Afghan Development Association (ADA) has given particular attention to the agricultural sector and rural activities, which contribute towards more productive and sustainable livelihoods at the grass-roots level with a strong focus on people centered approach in Afghanistan. Through a specific department ADA runs various projects under the Integrated Rural Development (IRD) Programmes and implemented many agriculture/horticulture development projects with a visible positive impact on the beneficiaries and played significant role in the improvement of living standards of people and briefly the whole population of target areas has been benefitted directly and indirectly in Afghanistan.
ADA's fields of interest and working area including of following:

- Agriculture

- Horticulture

- Irrigation

- Livestock

- Increasing awareness and capacity building; such as, agriculture inputs, extension services, rehabilitation and improvement of infrastructures, veterinary clinics, BVW training, animal treatment, cross-cutting issues, provision of shelters, water supply, technical training, improved techniques, marketing

- Cooperative management and establishment

- Nursery establishment and livelihood support services. 


\section{ZABUL}

TRAINING BENEFICIARIES

No Description

128 BVW received refresher training in basic veterinary services

15 people trained in animal health education

15 farmers trained in Orchard Management

\section{FACILITIES \& DISTRIBUTION;}

No Description

(1) 6418 Vaccination of animals

14598 Deworming of animals

10061 Treatment of animals

320876 Vaccination of animals

5201 Deworming of animals

7597 Treatment of animals
No Description
(2) 3814 Vaccination of animals
2142 Deworming of animals
2267 Treatment of animals
46469 Vaccination of animals
7316 Deworming of animals
8659 Treatment of animals

\section{ACTIVITIES}

\section{No Description \\ 12 Demonstration orchard survey \\ 2 Location identified for mother-stock nursery}

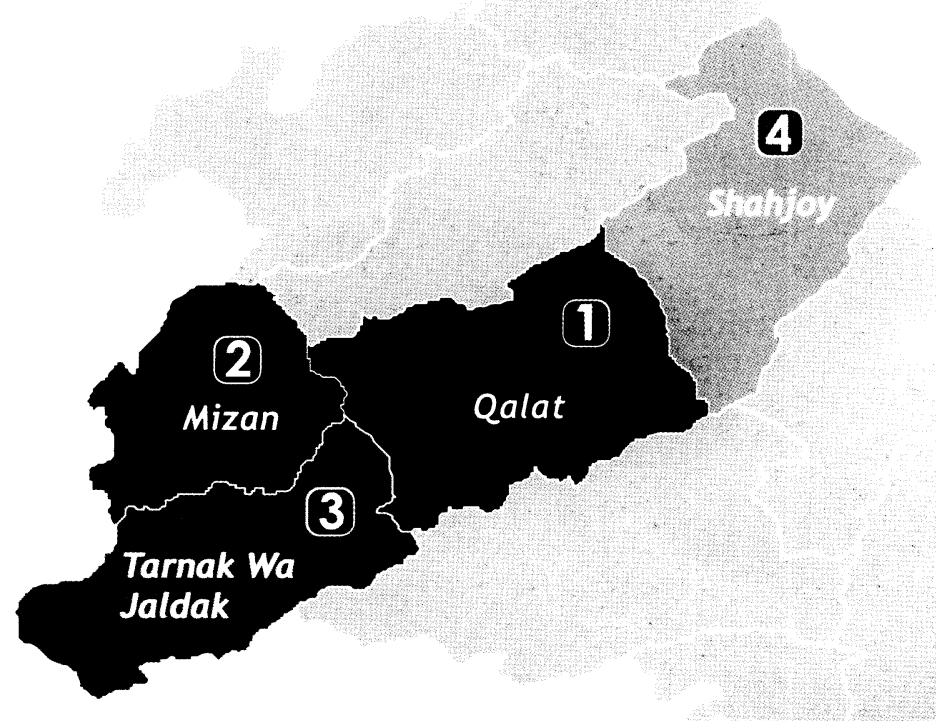




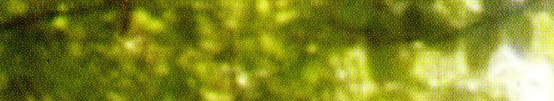

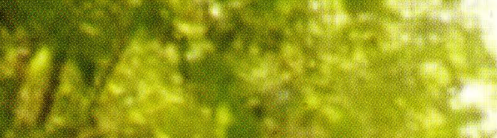

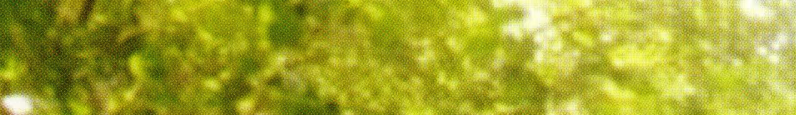

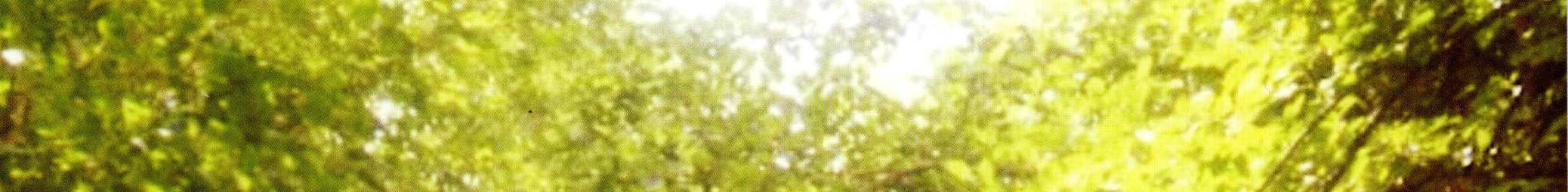

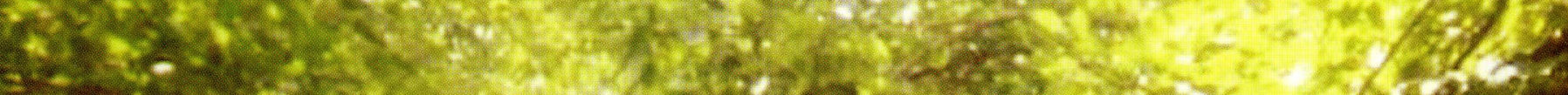

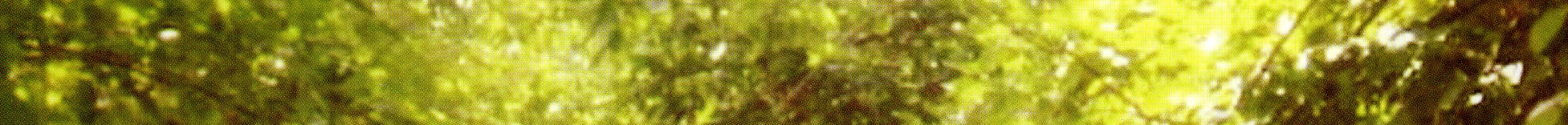

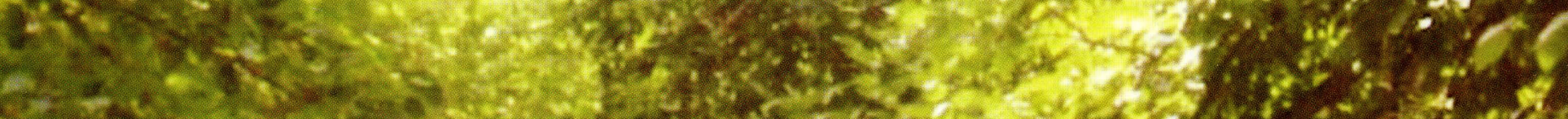

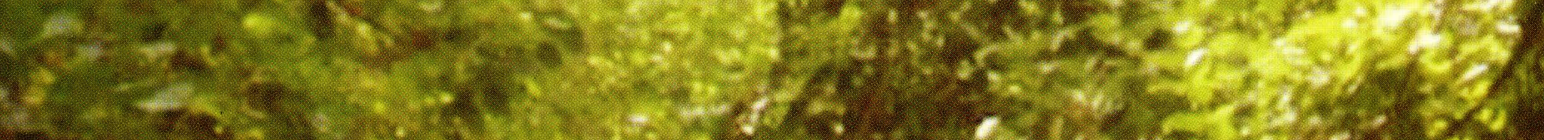
tis -

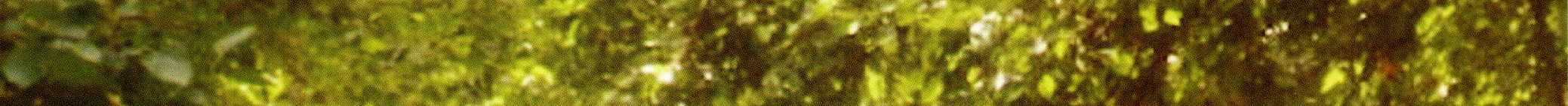

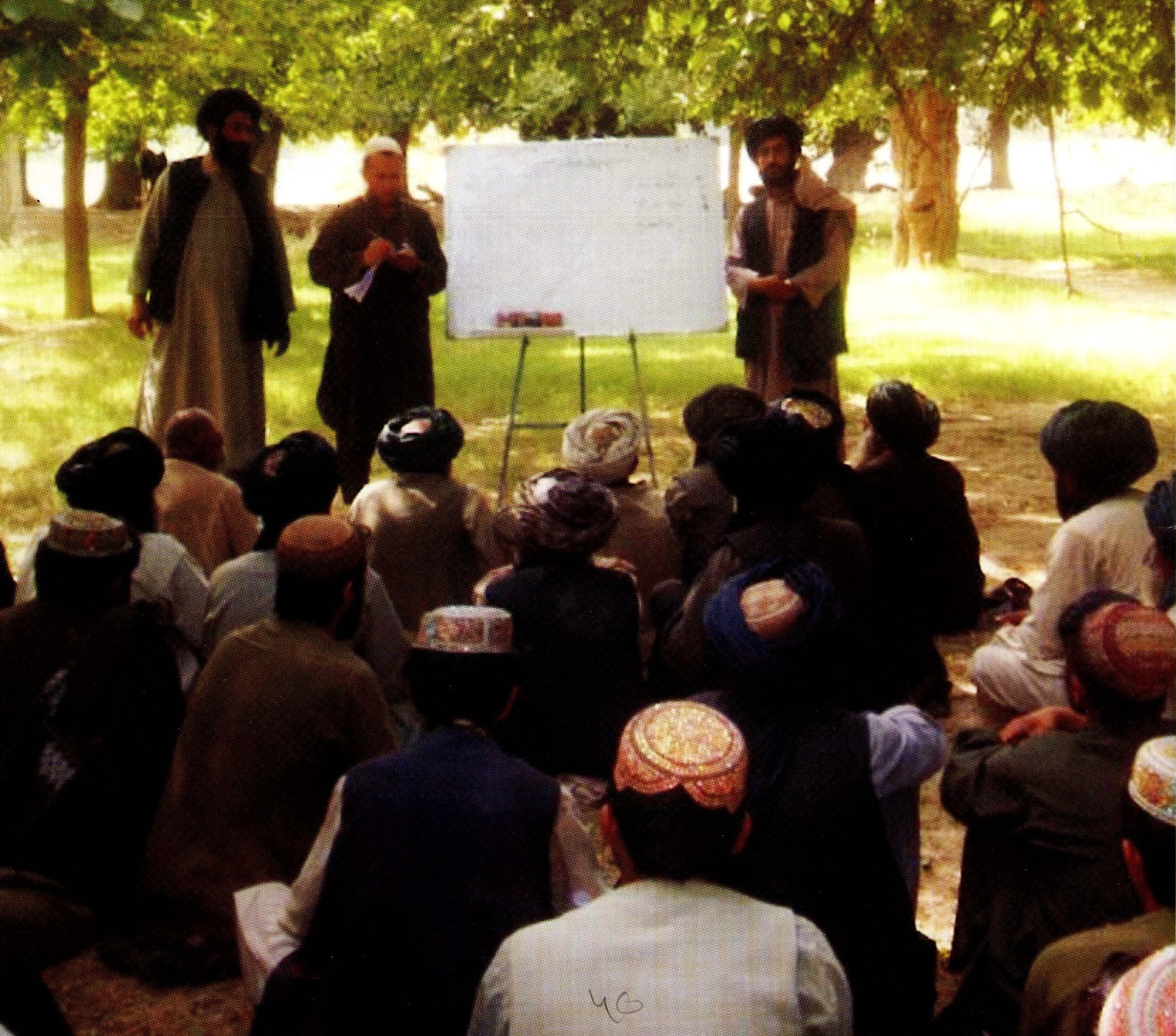




\section{URUZGAN}

TRAINING BENEFICIARIES

$\begin{array}{llll}\text { No } & \text { Description } & \text { No } & \text { Description } \\ 100 & \text { People in Cross Cutting Issues } & 20 & \text { Mechanics in hand pump installation } \\ 700 & \text { People in Hygiene education } & 50 & \text { Farmers on adopting new Apricot drying } \\ & & \\ 50 & \text { Farmers in best agl practices, pest/diseases control, pruning, budding of fruit trees. } \\ 30 & \text { Farmers trained Nursery / orchard management } \\ 800 & \text { Farmers trained in crop Management } \\ 200 & \text { Members of agriculture Shuras trained in cross cutting issue and Women trained in poultry } \\ 80 & \text { People Received kitchen garden training } \\ 60 & \text { Farmers trained in harvest and post harvest in Almond and Apricot, } \\ 2500 & \text { Farmers received technical assistance }\end{array}$

\section{FACILITIES \& DISTRIBUTION;}

$\begin{array}{lll} & \text { No } & \text { Description } \\ 54 & \text { Wells constructed } & \text { Latrines constructed, } \\ 25 & \text { Agriculture Cooperative Established } \\ 1 & & \\ 200 & \text { Farmers provided extension services } \\ 20 & \text { Canals with length of } 10 \text { km cleaned } \\ 140 & \text { Demonstration orchard established } \\ 800 & \text { Provided wheat seed, DAP, UREA \& } \\ & \text { basic agriculture tools } \\ 1400 & \text { Fruit saplings } \\ 50 & \text { Kitchen garden established } \\ 2500 & \text { Distribution of Kits of wheat Seed and fertilizer } \\ 120 & \text { MT wheat seed, MT DAP and MT Urea Distributed } \\ 1 & \text { Poultry farm and Fruit nursery Established } \\ 200 & \text { Women received poultry kits } \\ 150000 & \text { Corporative received as credit }\end{array}$

\section{ACTIVITIES:}

No

\section{Description}

Water Committee established

10 Farmers \& co-members are provided exposure visits

$45 \quad$ Relevant people are provided marketing seminars

2500 beneficiaries Identification and survey of poor farmers

220 Women survey for poultry and KG

500 Survey for hygiene education

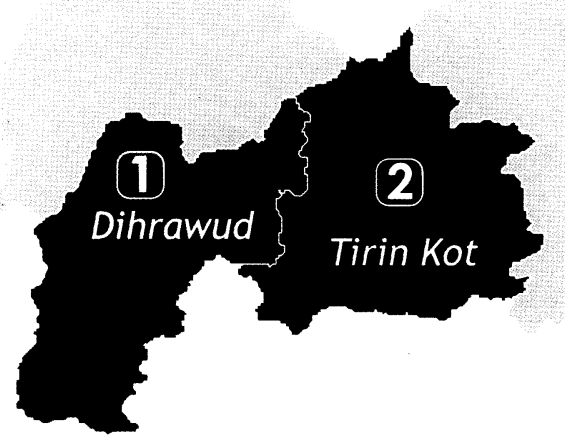

AFGHANISTAN DEVELOPMENT ASSOCIATION 



\section{KANDAHAR}

TRAINING BENEFICIARIES

No Description

143 Farmers trained in Marketing section

$27 \quad$ Nursery growers trained in fruit trees nursery industry

12 Farmers trained in building material

240 Farmers trained in Marketing section

60 Nursery growers trained in fruit trees nursery industry

322 BVW received veterinary refresher training

420 Women trained in animal feed preparation

FACILITIES \& DISTRIBUTION;
No Description
(1) 50 Drying houses Constructed
321309 Treatment of animals
44407 Vaccination of animal
9685 Treatment of animals

\section{ACTIVITIES:}

(1) 397 Fruit orchard survey

(2) 100 Nursery grower survey

(3) 21309 Survey of animals

(n)




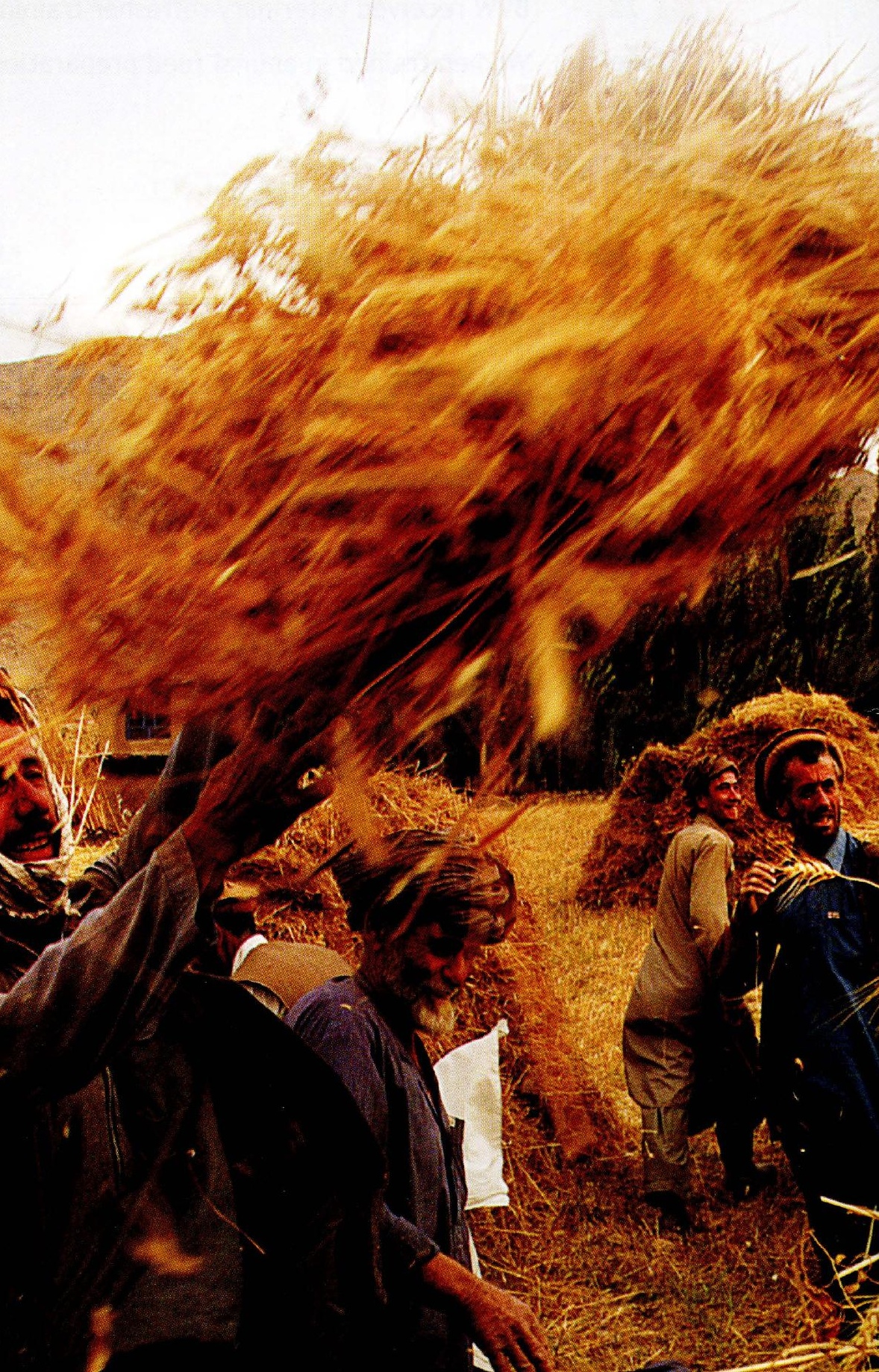




\section{NANGARHAR}

TRAINING BENEFICIARIES

No Description

11 gardener trained in orchard establishment

20 farmers trained in crop management

7 farmers trained in establishment of farmers association

24800 Farmers trained in Crop Management

3

4

FACILITIES \& DISTRIBUTION;

No Description

(1) Irrigation structure constructed

$48 \quad$ Farmers received technical assistance

5 Demonstration orchards established

20 Poultry kits distributed

$1 \quad$ Fruit trees nursery established
ACTIVITIES:

No Description

11 Marketing Seminar conducted

35 cooperative member conducted exposer visit

24800 Farmers received agriculture inputs

3

4

(wheat seed+Urea+DAP), post-harvest metallic storage silo kit, kitchen-garden vegetable Seeds

4

Dara-abones

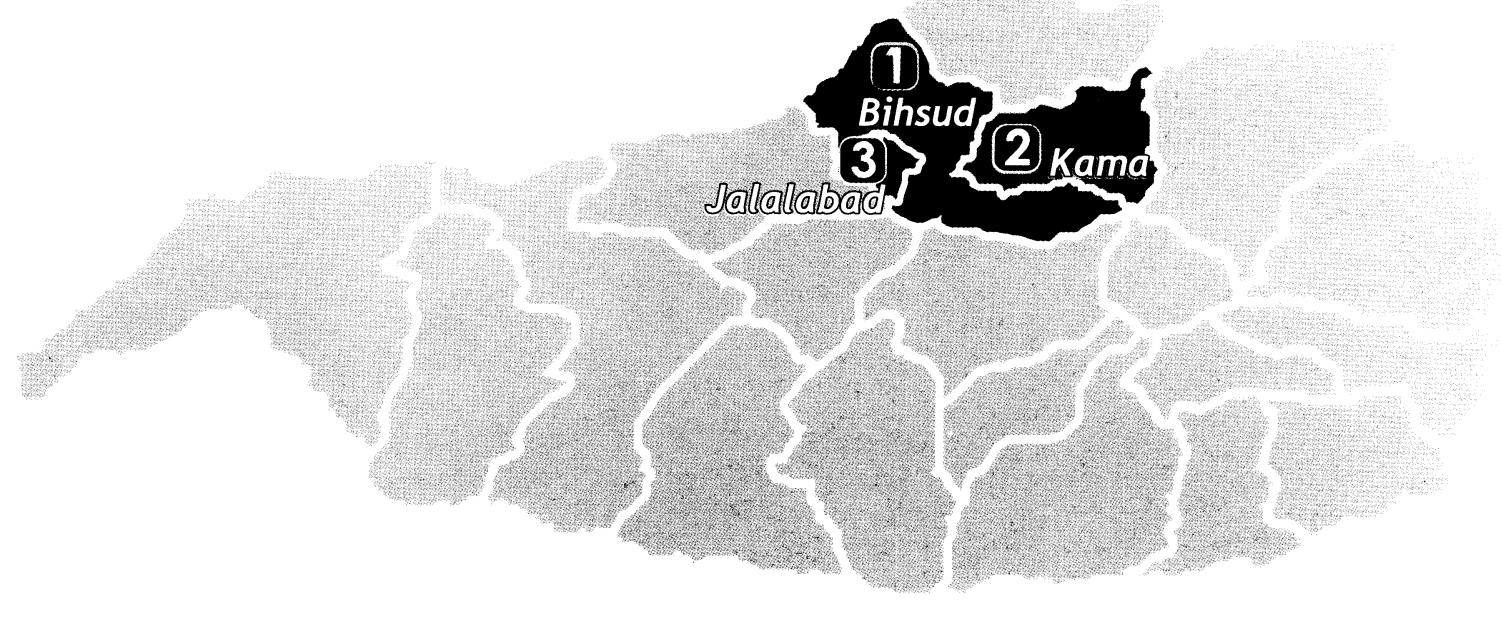





\section{DAIKUNDI}

\section{TRAINING BENEFICIARIES}
No
Description

11600 Farmers trained in Orchard Management

34 Governor staff trained in Orchard Management Only nele

10 ADA staff trained in Orchard Management

1600 Farmers trained in Crops Management

FACILITIES \& DISTRIBUTION;

No Description

1600 Demonstration Orchards Established each district

1600 Farmers received agriculture and horticulture kits 160,000 Fruit tree sapling distributed

\section{ACTIVITIES}

\section{Survey of farmers 16000 garden location survey}

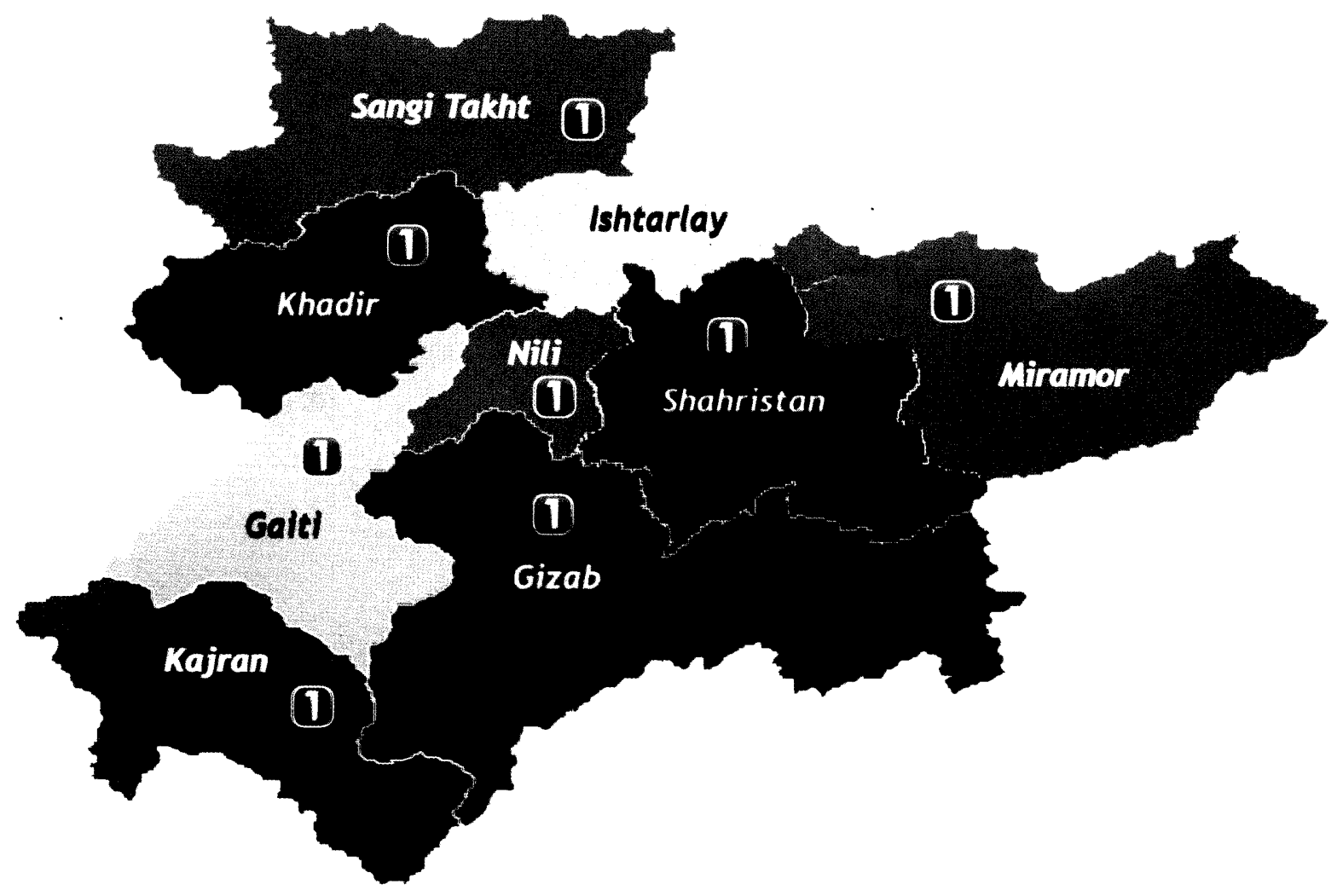




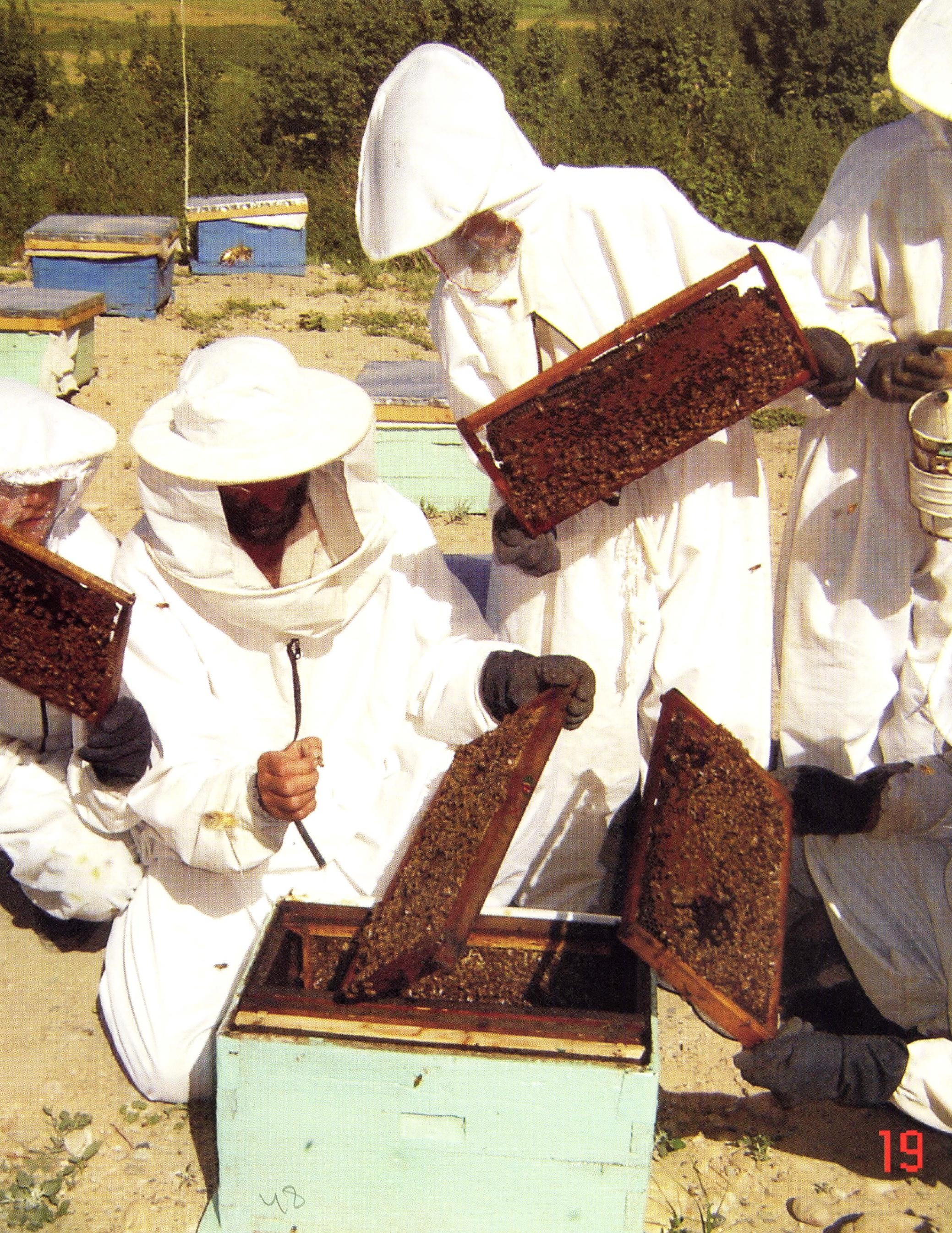




\section{GHAZNI}

\section{TRAINING BENEFICIARIES}

No Description

(1) 29 women trained in embroidery and marketing

12 people trained in water management

\section{FACILITIES \& DISTRIBUTION;}

No Description

128 women received embroidery kits

3544 Deworming of animals

2 irrigation structure constructed

1 Women shura established with 101 member

1 Project shura established with 10 member
No Description

2 Demonstration/training/

multiplication form established

(2) 4597 Vaccination of animals

3544 Deworming of animals

3739 Treatment of animals

2 Demonstration/training/

multiplication form established

\section{ACTIVITIES}

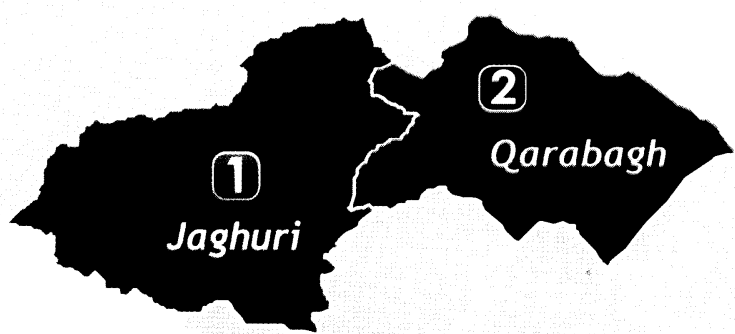

No Description

1 Marketing seminar conducted

15 Farmer conducted exposer visit

21 Marketing seminar conducted

15 Farmer conducted exposer visit

$2 \quad$ Fruit growers cooperative supported

Nawa 
10.

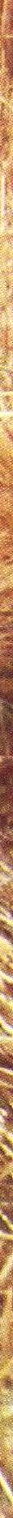




\section{BAGHLAN}

\section{TRAINING BENEFICIARIES}

No Description

124 farmers trained in plant protection management

20 women trained in poultry

6 Farmer trained in orchard management

10 Farmer trained in budding and ploning

FACILITIES \& DISTRIBUTION

\section{No Description}

120 Women received poultry kits

40 KG seed provided for nursery

1 Fruit tree nursery established

6 Demonstration orchard established

\section{ACTIVITIES}

No Description

(1) 20 Farmer recelved technical assistance

6 Demonstration orchard survey

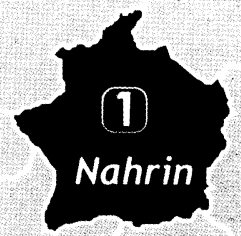




\section{Agriculture \& Livestock summary of activities during - 2010}

\section{PROVINCES}

Uruzgan, Daykundi, Kandahar, Zabul, Nangarhar, Baghlan, Ghazni

DONORS:

NCA, MCN, IFC, EC-MADERA, FAO, NOVIB,

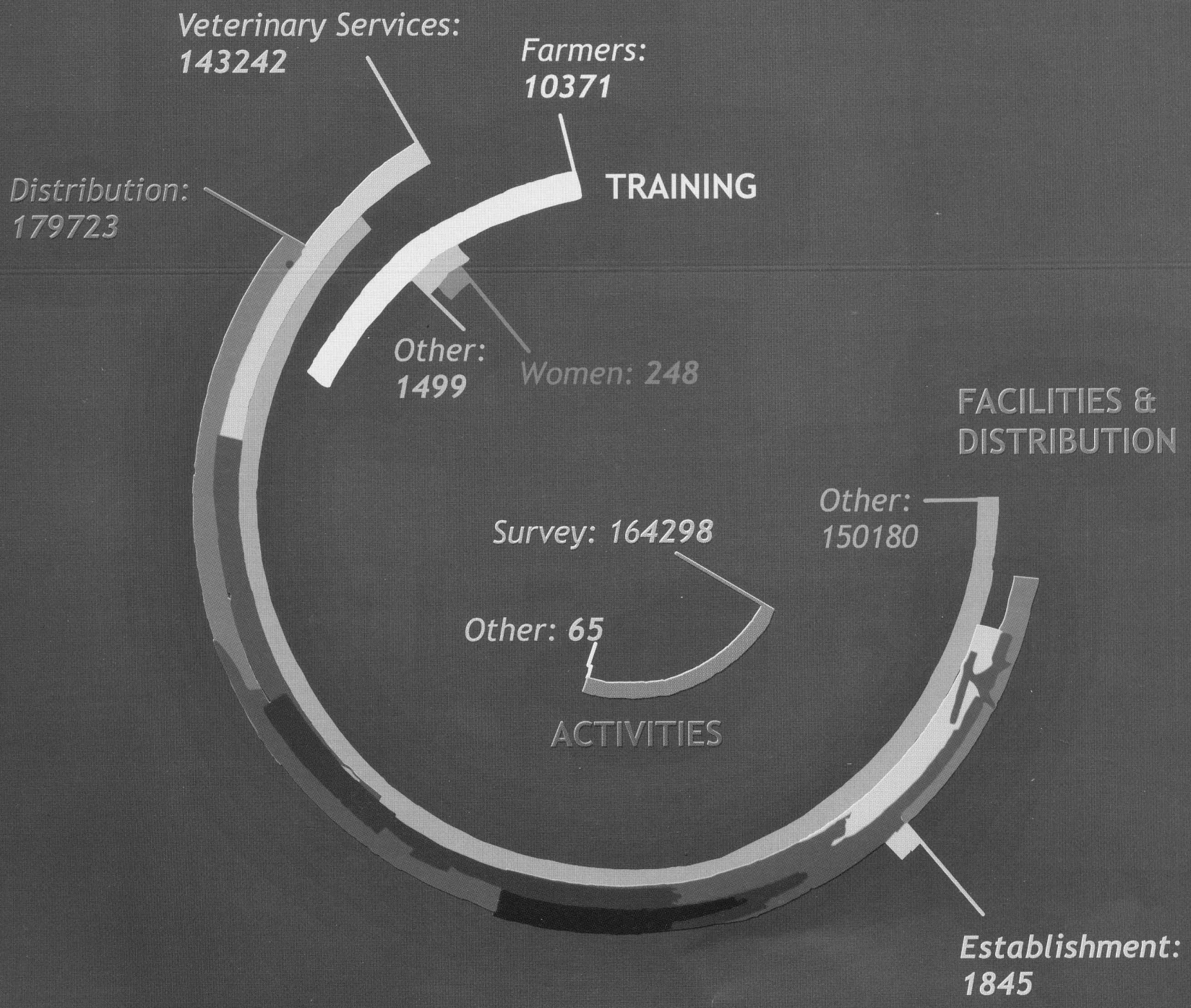




\section{EXPENDITURE FOR THE YEAR - 2010 AGRICULTURE \& LIVESTOCK DEPARTMENT}

Total Budget: $\quad \$ 1,955,995.00 \quad$ Afg $91,931,765.00$

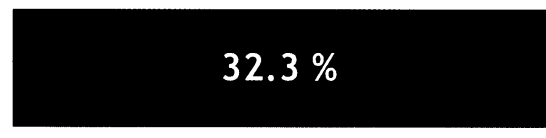

MCN

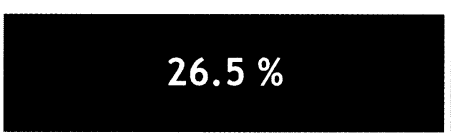

IFC

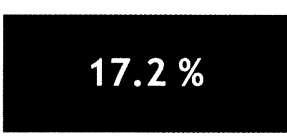

NCA

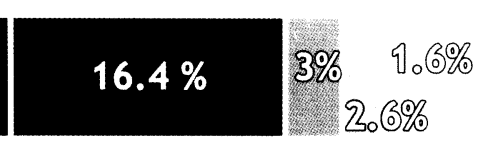

Novib

FAO EC CWS
Total

Duration

Project Budget

Satus

\section{MCN}

Consulting Services for Orchard Establishment \& Development

Nov 09 - Dec 10

$\$ 653560$ Completed

IFC

Horticulture Cluster Development

Mar $10-\operatorname{Dec} 11$

$\$ 1274849$ Ongoing

\section{NCA}

Horticulture Development

Food Security \& Agriculture Livelihood Packages

Water Supply, Sanitation, Irrigation and Hygiene - P II

\section{Novib}

Integrated Rural Program

\section{FAO}

Animal Feed Distribution

Wheat Seed \& Fertilizer Distribution - Autumn 2009

Food Security \& seed Distribution

EC

Perennial Horticulture Development

Support to Fruit Tree Nursery Industry

\section{CWS}

Food Security Project
Jan $10-\operatorname{Dec} 10$

Jan 10 - Dec 10

May 10 - Sep 10

Sep 08 - Aug 11

$\$ 1125047$ Completed

Dec 09 - Mar 10

Sep 09 - Apr 11

Aug 10 - Nov 11

Mar 07 - May 10

Sep $10-\operatorname{Dec} 13$

Nov 08 - Aug 10
$\$ 57377$ Completed

$\$ 243328$ Completed

$\$ 42579$ Completed

$\$ 16818$ Completed

$\$ 47500$ Completed

$\$ 120000$ Ongoing

$\$ 975646$ Completed

\$318736 Ongoing

$\$ 578715$ Completed 



\section{PROJECT FUND FLOW | 2002 - 2011}

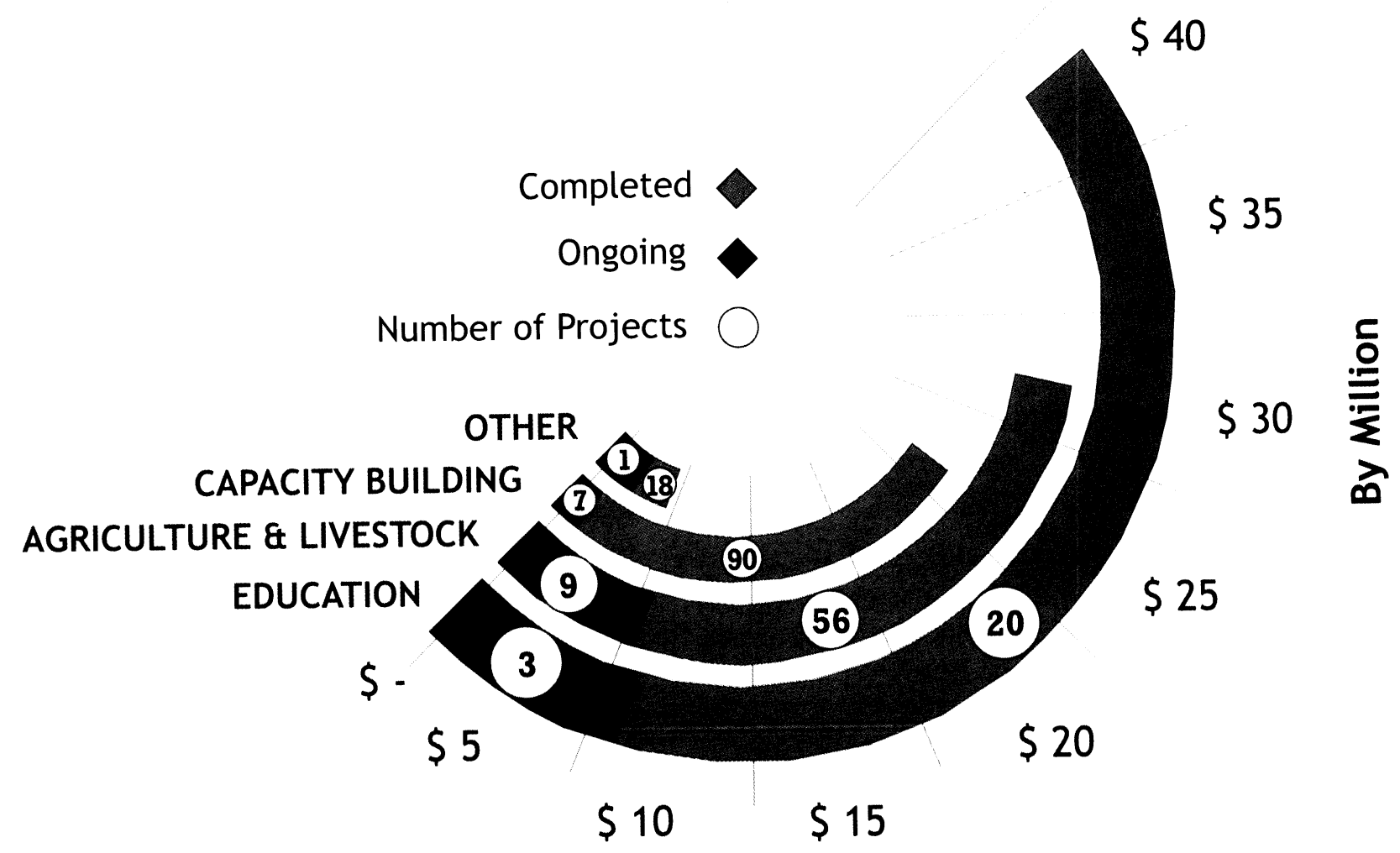

\section{DONOR/SUPPORTER LIST}

- MoE

- MOCN

- MAIL

- MOLSMD

- MRRD

- USAID

- Care International Afghanistan

- European Commission (EC)

- Christian Aid (CA)

- Netherlands Embassy Kabul (NEK)

- Norwegian Church Aid (NCA),

- World Bank (WB)

- Netherlands Organization for International Development (NOVIB)/Oxfam,

- Church World Services (CWS)

- United Nation Food and Agriculture Organization (UN FAO)
- The Asia Foundation (TAF)

- Creative Associates International Inc. (CAIl/USAID)

- Roots of Peace (RoP)

- Association for Rural Development (ARD/USAID)

- Government of Canada/Embassy of Canada/Canada Fund

- Development Alternatives Inc. (DAI/USAID)

- Department of International Development (DFID)

- International Rescue Committee (IRC)

- Trocaire/Cafod (TC)

- Counter Part International (CPI)

- International Finance Corporation-IFC World Bank Group-WBG (IFC-WBG) 


\section{FINANCIAL REPORT - 2010}

\section{Policies:}

ADA operates through a well-established Finance Setup providing control from Head Office level to all the way to provincial, field and project site offices. Our financial procedures have evolved over the years to accommodate technical and legal requirements of Government of Afghanistan (GoA), while at the same time in tune with modern systems and management to ensure efficiency and transparency in operations. Annual audit is conducted every year by an independent auditing firm regularly.

\section{Expenditure:}

Financial data and reports are shared with relevant stakeholders for activities of concern; for the mentioned 12 month period, budget utilized by programme departments for respective sectors of interest, which has been highlighted in the adjacent diagrams. As shown, the total expenditures in this period were $\$ 11,111,957$. For more information, the below diagrams are designed to provide sectoral wise expenses, which took place during the period of 12 months from January to December 2010.

\section{Analysis of Expenditure:}

The diagrams illustrate the relative size of the major expenditure categories of ADA during the whole year. Furthermore, the diagrams show that education and training expenditure during this period accounted for $69.86 \%$ of total expenditures, while our capacity building programme accounted for a further $0.97 \%$ of expenditures. The Integrated Rural Development Programme accounted for $27.54 \%$ of expenditures. The total operations and administration costs of ADA in this period accounted for only $1.95 \%$ of expenditures. As expressed above, ADA believes that this represents a high level of efficiency and excellent value for money for our donors.
ADA is the prime contractor with Ministry of Education (MOE) for the Teacher Training - DT3 Programme in 8 respective provinces of Afghanistan; such as, Kapisa, Laghman, Kabul, Parwan, Paktia, Paktika, Logar and Bamyan. ADA implements the programme in two provinces while the rest 6 provinces are subcontracted to other reputable Afghan NGOs; alike, CHA, AWEC and CoAR. The Teacher Training (DT3) expenditure is shown for the subcontractors as well as for ADA in the following diagrams.

\section{EXPENDITURE: JANUARY - DECEMBER 2010} Total: USD 11,109,557

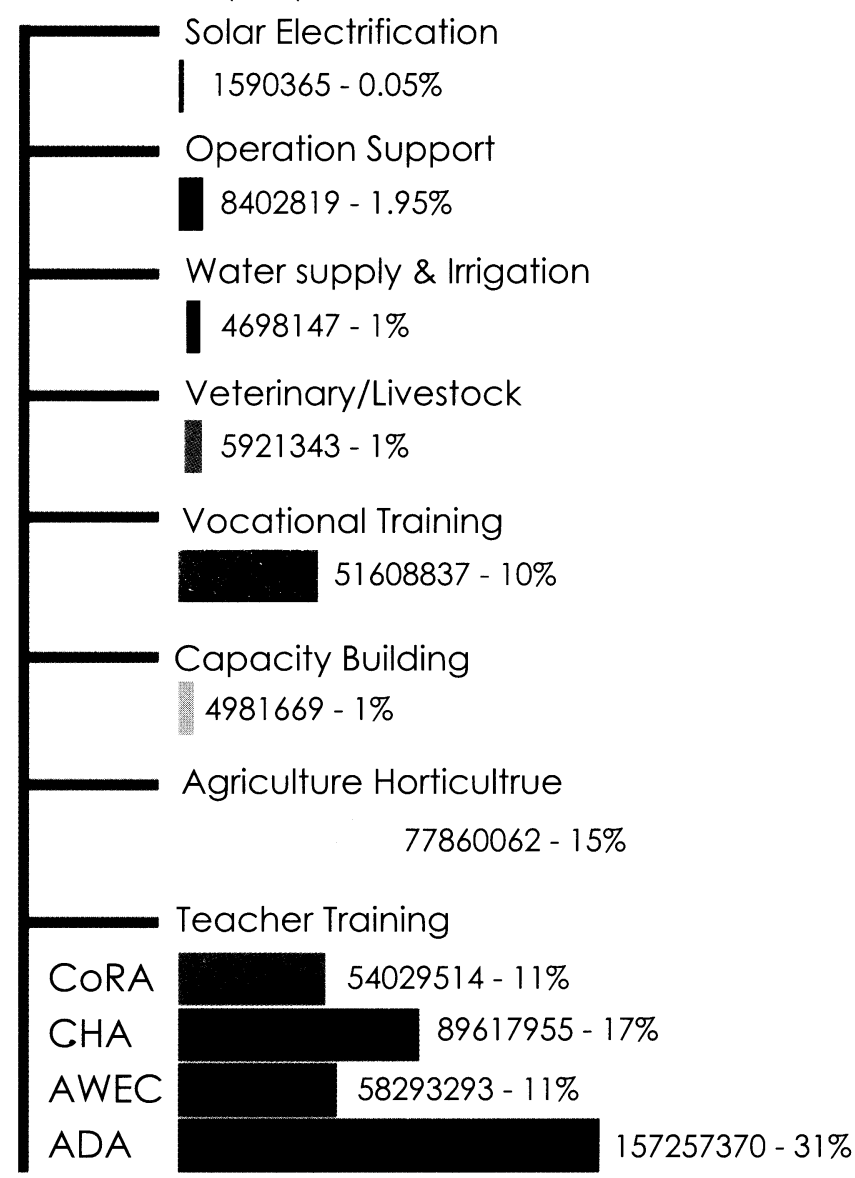




\section{THE WAY FORWARD \& FUTURE PLANS}

ADA has looked into its 2010 year overall programme management and implementation aspects to see what listens can be learnt and how to prepare ADA with an upgraded, effective, with quality, and result driven approaches and strategy that can have with even more quality and efficient results. As a result, ADA came up with substantive changes to the whole system. The main components of these changes will be:

Re-structuring. ADA's current structure will be reviewed more deeply and the required changes will be made that can better maintain quality and efficiency. Emphasis will be made on the recruitment of qualified and experience people. Restructuring will start from main office and will be extended to the field offices.

Develop/update/upgrade Strategic WorkPlan, Policies and Procedures. ADA will develop a five years strategic work-plan and will develop/update/upgrade the current policies, manual and procedures e.g. HR Policy, Financial Management Policy, Travel Policy, Procurement Policy and Attendance Procedure looking into the current substantial changes into non-forprofit organization system both locally and globally.

Communication and Coordination System. Establishment of effective communication system between centre and provinces. This system will be used to ensure proper connection and communication between central and provincial offices.

Capacity Building \& Institutional Development. ADA will further strengthen the capacity of main office and provincial offices, increase focus on recruitments of qualified and experienced people and support the development of new systems and structures; such as, Information Management System (IMS),
Financial Management (FM), Internal Audit (IA), and Staff Capacity Building (SCB).

Performance Management and Reporting. ADA will strengthen its system for monitoring activities, outputs and achievements on agreed work plans and log frames. This will improve its operational effectiveness. ADA will continue to further enrich and refine monthly, quarterly and annual reporting system and will pay more attention on the quality of reports.

Financial Management \& Information Management Systems. ADA will improve the quality of information available to management in several areas. ADA will develop an electronic system for its Finance Department, Human Resources and Administration Department including comprehensive financial reporting system. Other information systems will be developed, which will include Human Resources Database and electronic attendance system and electronic inventory system.

Website: ADA will upgrade the website that enables an ongoing conversation among ADA collaborators (government officials, donor, and private sector) about the progress and challenges of ADA implementation at the country level. The website is the main forum for communicating and reporting from center to province. The website also informs the general public about ADA activities and services.

The ADA site will provide a credible, stable image that reflects the dual governmental and donor nature of this initiative and the main audience for this website. Given ADA's close connection to the open data/knowledge movements and the need to 'practice what we do' the site will be an open source platform and reflect the ADA aim's values. 


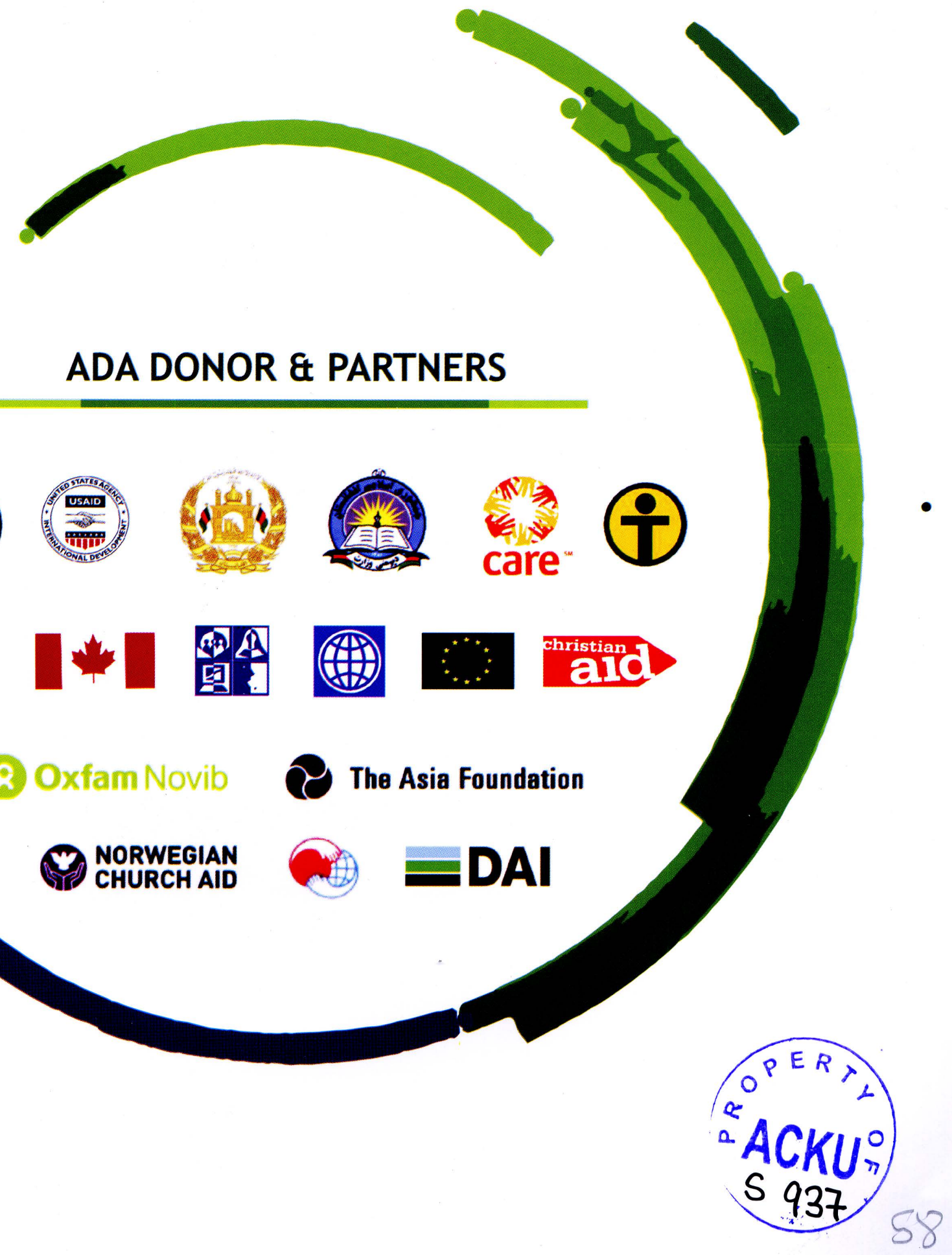


Deaigned by: Ahmad Kakar | me.kakar@gmall.com

6 


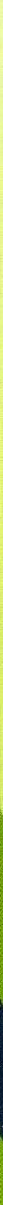

\section{ADDRESS | HEAD OFFICE}

House No 264 - 265, Kabul River Bank, Pul-e-Surkh, Kart-e-Chahar, Kabul, Afghanistan

Cell: +93 (0) 7991188 40, 7992021 37, 799608074

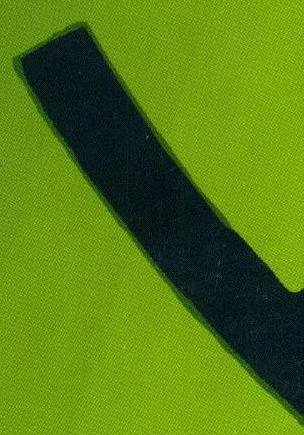

PO Box: 199 Kabul | Fax: +93 (0) 776100170

Email: info@ada.org.af | Website:www.ada.org.af 